\title{
A IMUNIDADE TRIBUTÁRIA DOS TEMPLOS E O CONCEITO DE RELIGIÃO NO SUPREMO TRIBUNAL FEDERAL
}

\author{
THE TEMPLES TAX IMMUNITY AND THE CONCEPT OF RELIGION IN THE \\ BRAZILIAN SUPREME COURT
}

\section{LA INMUNIDAD FISCAL DE LOS TEMPLOS Y EL CONCEPTO DE RELIGIÓN EN LA CORTE FEDERAL SUPREMA}

\author{
ROGÉRIO ROBERTO GONÇALVES DE ABREU \\ http://orcid.org/0000-0002-0869-2617 / http://lattes.cnpq.br/6757724368801194 / abreu.rrg@gmail.com \\ Centro Universitário de João Pessoa (UNIPÊ/PB) \\ João Pessoa, PB, Brasil.
}

HÉLIO SILVIO OURÉM CAMPOS

http://orcid.org/0000-0001-6162-7024 / http://lattes.cnpq.br/1508584545879443 / ouremcampos@hotmail.com Universidade Católica de Pernambuco (UNICAP/PE) Recife, PE, Brasil.

VIRGÍNIA COLARES http://orcid.org/0000-0001-9057-7927 / http://lattes.cnpq.br/7462069887119361 / virgínia.colares@gmail.com Universidade Católica de Pernambuco (UNICAP/PE) Recife, PE, Brasil.

\begin{abstract}
RESUMO
O objetivo do artigo é discutir - a partir do exame de decisões colegiadas sobre imunidade tributária dos templos de qualquer culto - se e como o Supremo Tribunal Federal estabeleceu a ideia de religião. Inicialmente, chamamos a atenção para a importância dos conceitos na definição de direitos e obrigações, sobretudo na área tributária. Em seguida, apresentamos as linhas gerais da temática da imunidade tributária dos templos a partir da Constituição e da doutrina. Em seguida, descrevemos o procedimento de coleta e seleção do material que integrou o corpus de pesquisa, obtido na página web do STF e composto por decisões sobre imunidade tributária dos templos de qualquer culto. Desse modo, identificamos o RE 562.351/RS como a única decisão em que o conceito de religião foi realmente discutido. A seguir, analisamos textualmente o voto do relator, as notas sobre os debates e o voto-vista divergente. Ao final, concluímos que, a despeito de o STF decidir sobre direitos, deveres e obrigações tributários com base na ideia de religião, a corte, colegiadamente, jamais conceituou o que deva ou possa ser considerado religião ou religioso.
\end{abstract}

Palavras-chave: Conceito de religião; Supremo Tribunal Federal; Templos de qualquer culto.

\section{ABSTRACT}

We want to discuss - through the exam of decisions on temples tax immunity - whether and how the Brazilian Supreme Court has established the concept of religion. First, we point out the importance of concepts regarding the definition of rights and obligations, especially in tax law. Second, we present the general grounds on temples tax immunity within the Federal Constitution of Brazil and the law doctrine. Third, we described the procedure of gathering and selection of the material we handle as a corpus, found at the Supreme Court's website and formed by decisions on temples tax immunity. The exam and classification of this material allowed us to identify the RE $562.351 / R S$ as the only decision whereby the concept of religion has been really discussed. Next, we analyzed the text of the opinions of each judge who took part in the decision. Finally, we concluded that, despite the fact that the Brazilian Supreme Court rules about tax rights, duties and obligations based on the idea of religion, the court, in a plural composition, has never reached to a concept about what has or can be considered religion or religious.

Keywords: Brazilian Supreme Court; Concept of religion; Temples tax immunity. 


\section{RESUMEN}

El objetivo del artículo es discutir - a partir del examen de decisiones colegiadas sobre inmunidad tributaria de los templos de cualquier culto - si y cómo el Supremo Tribunal Federal estableció la idea de religión. Inicialmente, llamamos la atención sobre la importancia de los conceptos en la definición de derechos y obligaciones, sobre todo en el la área fiscal. A continuación, presentamos las líneas generales de la temática de la inmunidad tributaria de los templos a partir de la Constitución y de la doctrina. Siguiendo, describimos el procedimiento de recolección y selección del material que integró el corpus de investigación, obtenido en la página web del STF y compuesto por decisiones sobre inmunidad tributaria de los templos de cualquier culto. De ese modo, identificamos el RE 562.351 / RS como la única decisión en que el concepto de religión fue realmente discutido. A continuación, analizamos textualmente el voto del ponente, las notas sobre los debates y el voto-vista divergente. Al final, concluimos que, a pesar de que el STF decide sobre derechos, deberes y obligaciones fiscales en base a la idea de religión, la corte, colegiadamente, jamás conceptuó lo que deba o pueda ser considerado religión o religioso.

Palabras-clave: Concepto de religión; Inmunidad fiscal de los templos; Supremo Tribunal Federal.

\section{SUMÁRIO}

INTRODUÇAO, 1 A IMUNIDADE TRIBUTÁRIA DOS TEMPLOS DE QUALQUER CULTO, 2.2 ANÁLISE DOS JULGADOS DO STF SOBRE A MATÉRIA, 3 O JULGADO PARADIGMA: RE 562.351/RS, 3.10 voto impresso do relator, 3.20 debate entre os ministros, 3.30 voto-vista, CONCLUSÃO, REFERÊNCIAS.

\section{INTRODUÇÃO}

A forma como a Constituição Federal organiza, estrutura e disciplina o poder judiciário brasileiro confere ao Supremo Tribunal Federal a função de guardião da ordem jurídica constitucional. No desempenho dessa atribuição, o STF não apenas exerce o controle abstrato de constitucionalidade das leis e atos normativos do poder público, mas decide, em caráter definitivo e nos casos concretos, questões de compatibilidade com a Constituição e de titularidade e exercício de direitos e garantias fundamentais. O STF, portanto, julga demandas entre partes, decidindo sobre direitos, deveres e obrigações na ordem constitucional, atuação que o distingue de um simples órgão de uniformização de jurisprudência ou mesmo de uma autêntica corte constitucional.

A natureza analítica da Constituição Federal de 1988, compreensiva de notável diversidade de matérias, tem como resultado mais evidente o imenso volume de demandas que aportam ao Supremo Tribunal Federal pela via recursal, sempre a exigir da corte, no caminho do julgamento da causa, a uniformização da interpretação da norma constitucional quanto à titularidade e ao exercício de direitos constitucionais. Entre as questões que mais demandam a atenção do STF, podemos apontar as de natureza tributária, as quais encontram na CF/88 disposições normativas que, superando a generalidade própria às Cartas Constitucionais, minudenciam a disciplina da função arrecadatória do Estado a ponto de criar uma verdadeira 
ISSN 1981-3694

(DOI): $10.5902 / 1981369435079$

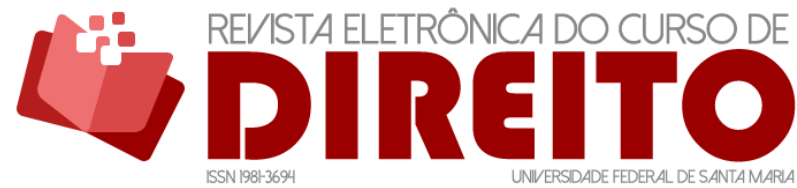

A IMUNIDADE TRIBUTÁRIA DOS TEMPLOS E O CONCEITO DE RELIGIÃO NO SUPREMO TRIBUNAL FEDERAL

ROGÉRIO ROBERTO GONÇALVES DE ABREU HÉLIO SILVIO OURÉM CAMPOS VIRGÍNIA COLARES

“ordem constitucional tributária". Em razão disso, o STF, constantemente, decide demandas tributárias a partir da Constituição Federal, julgando controvérsias constitucionais a envolver entidades da Fazenda Pública em todas as esferas estatais, de um lado, e os contribuintes, pessoas físicas e jurídicas, de outro.

No desempenho dessa tarefa, os ministros lidam, necessariamente, com todo o vocabulário próprio aos problemas de natureza tributária para estabelecer os limites que separam a atividade estatal de arrecadação e os direitos e garantias dos súditos de não se verem tributados além daquilo que permite a ordem constitucional. Nesse particular, a palavra "vocabulário" ganha importância, pois a norma que define tributos precisa descrever, a partir de conceitos precisos, os elementos do fato sobre que deverá incidir para fazer surgir a obrigação tributária. É necessário ao legislador, portanto, descrever o fato gerador do tributo, individualizando a parcela da realidade que, uma vez verificada, fará surgir a obrigação de pagar determinado tributo e, para isso, tanto quanto no direito penal, não poderá se servir de conceitos imprecisos e equívocos.

É preciso, pois, atentar para a importância do manejo dos conceitos para a definição de direitos e obrigações em matéria tributária e, mais destacadamente, para o processo de tomada de decisão sobre o reconhecimento judicial desses direitos e obrigações tributários, atividade constantemente exercida pelo Supremo Tribunal Federal, seja nos controles abstrato e concreto de constitucionalidade, seja na aplicação do direito constitucional à lide judicializada, mas, em qualquer caso, em caráter definitivo.

Daí a pergunta: será que o Supremo Tribunal Federal, no desempenho dessa atividade de julgar questões sobre direitos e deveres tributários, tem atentado para a necessária precisão dos sentidos atribuídos aos conceitos por si utilizados, eis que incorporados pelo constituinte e pelo legislador infraconstitucional na composição do sistema normativo tributário brasileiro? Considerando que a imprecisão desses conceitos pode implicar decisões mal formadas a partir de processos de tomada de decisão defeituosos, a questão nos pareceu suficientemente relevante a motivar o trabalho de pesquisa aqui apresentado.

No presente artigo, a partir do emprego de instrumentos metodológicos de investigação empírica exploratória e qualitativa, procuramos responder a seguinte questão, que nos serve de problema de pesquisa: como o Supremo Tribunal Federal vem apreendendo e utilizando o conceito de religião em acórdãos que cuidam do reconhecimento da imunidade tributária dos “templos de qualquer culto"? Teria, no processo de tomada de decisão nesses casos, 
estabelecido e fixado o conceito de religião? Teria se apropriado de conceito já cristalizado na doutrina ou em precedentes de outros tribunais? São perguntas que merecem atenção.

Realizados os trabalhos empíricos de base a partir do corpus, hipotetizamos que, embora o Supremo Tribunal Federal julgue demandas sobre direitos, deveres e obrigações em matéria tributária com base na ideia de religião e seus derivados (religioso, religiosidade etc.), o tribunal - como órgão colegiado de julgamento - jamais estabeleceu ou precisou, na fundamentação de decisões sobre imunidade tributária dos "templos de qualquer culto", o conceito de religião.

No desenvolvimento da investigação, realizamos pesquisa bibliográfica em livros e artigos doutrinários sobre dois temas, com função eminentemente ancilar. No primeiro caso, caracterizamos as linhas gerais da imunidade dos templos de qualquer culto no direito brasileiro com o objetivo de contextualizar o problema no campo teórico em que se situa e em que adquire maior relevância. No segundo caso, empregamos as fontes que traduzem tentativas doutrinárias de conceituar religião apenas para fornecer aos achados empíricos na pesquisa documental - e na consequente análise textual do acórdão do STF - um 'pano de fundo', colocando em contraste os fundamentos utilizados pelos ministros no julgado particularmente examinado.

Por fim, utilizamos a ferramenta de busca de jurisprudência do sítio virtual do STF para a coleta dos julgados que formaram o corpus de pesquisa, composto dos julgados correspondentes às decisões colegiadas do STF que apresentavam, em seu texto, referência escrita à matéria de imunidade tributária dos templos de qualquer culto. 0 procedimento de pesquisa será mais fielmente detalhado a seguir.

\section{A IMUNIDADE TRIBUTÁRIA DOS TEMPLOS DE QUALQUER CULTO}

O Estado brasileiro se formou em absoluta sintonia com o Cristianismo, como é possível intuir a partir dos dois primeiros nomes atribuídos pelos portugueses à terra descoberta: Ilha de Vera Cruz e Terra de Santa Cruz. A própria Constituição imperial enunciava em seu art. $5^{\circ}$ que "A Religião Católica Apostólica Romana continuará a ser a Religião do Império”" . Com o advento da República e da respectiva Constituição republicana, estabeleceu-se a separação entre o poder

1BRASIL. Constituição Política do Império do Brasil. Rio de Janeiro: outorgada pelo Imperador D. Pedro I, 1824. Disponível em: http://www.planalto.gov.br/ccivil_03/Constituicao/Constituicao24.htm. Acesso em: 03 jun. 2020. 
político e o poder religioso, adquirindo o Estado neutralidade em relação à Igreja e, ao mesmo tempo, assumindo o compromisso de respeitar todos os credos religiosos ${ }^{2}$. Surgia o estado laico brasileiro.

Nesse contexto, Ronaldo Lindimar José Marton analisa a transformação das relações entre o Estado brasileiro e a Igreja (em sentido lato) a partir do estudo comparado entre os textos das Constituiç̧̃̃es nacionais, assinalando que, a par da separação que caracteriza a natureza laica do Estado, o nível de integração ou distanciamento variava segundo a conjuntura política em que cada constituição teria sido elaborada e posta em vigor. No que diz respeito ao emprego da palavra "templo" pelas constituições brasileiras, o autor anota que a Constituição do Império ${ }^{3}$ a utilizava para garantir à Igreja Católica a prerrogativa do exercício do culto em edifícios públicos, ao mesmo tempo em que restringia as demais ao culto doméstico ou em casas não caracterizadas como templo. As Constituições de 1891, 1934 e 1937 não teriam utilizado a expressão. Com a Constituição de 1946, ainda segundo Ronaldo Marton, não apenas a palavra templo retornou ao texto constitucional, como também estabeleceu-se a respectiva imunidade tributária, quadro mantido até o advento da Constituição de $1988^{4}$.

De acordo com a Constituição de 1988 (art. 150, VI, 'b'), “é vedado à União, aos Estados, ao Distrito Federal e aos Municípios (...) instituir impostos sobre (...) templos de qualquer culto", esclarecendo que a vedação compreende apenas "o patrimônio, a renda e os serviços, relacionados com as finalidades essenciais" da entidade $\left(\$ 4^{\circ}\right)$. Como era de se esperar, a falta de paralelismo entre os textos da alínea ' $b$ ' e das demais alíneas do inciso VI do art. 150 da CF resultou em acesos debates acerca da extensão da imunidade tributária aos templos, exigindo dos juristas algum empenho no processo de compreensão, interpretação e aplicação da disposição constitucional em causa.

A mais direta interpretação da disposição constitucional pregava a restrição da imunidade tributária ao templo, identificando caso de imunidade objetiva, não necessariamente aplicável à respectiva organização mantenedora. Além disso, o âmbito semântico da palavra

\footnotetext{
${ }^{2}$ MARTON, Ronaldo Lindimar José. A imunidade tributária dos templos de qualquer culto na interpretação da Constituição adotada pelo Supremo Tribunal Federal. Consultoria Legislativa. Brasília, Câmara dos Deputados, fev. 2013. Disponível em: http://www2.camara.leg.br/a-camara/documentos-epesquisa/estudos-e-notas-tecnicas/areas-da-conle/tema20/CP13006_1.pdf. Acesso em: 20 ago. 2018. p. 6. ${ }^{3}$ BRASIL. Constituição Política do Império do Brasil. Rio de Janeiro: outorgada pelo Imperador D. Pedro I, 1824. Disponível em: http://www.planalto.gov.br/ccivil_03/Constituicao/Constituicao24.htm. Acesso em: 03 jun. 2020.

${ }^{4}$ MARTON, Ronaldo Lindimar José. A imunidade tributária dos templos de qualquer culto na interpretação da Constituição adotada pelo Supremo Tribunal Federal. Consultoria Legislativa. Brasília, Câmara dos Deputados, fev. 2013. Disponível em: http://www2.camara.leg.br/a-camara/documentos-epesquisa/estudos-e-notas-tecnicas/areas-da-conle/tema20/CP13006_1.pdf. Acesso em: 20 ago. 2018.
} 
“templo" exigia a conjunção com a ideia de "religião", de modo que templos seriam apenas aqueles em que se realizassem "cultos religiosos".

Fabiana Ávila ensina que "deve possuir o culto requisitos mínimos de espiritualidade e transcendentalidade, para ser guinado ao patamar de religião"6. Adepta de uma posição mais restritiva sobre a imunidade tributária do art. 150, VI, 'b', a autora sustenta que atividades econômicas próprias do setor privado, quando exercidas por entidades religiosas, não poderiam ser protegidas da tributação, nem mesmo sob o fundamento de que seus frutos econômicos seriam aplicados nas finalidades essenciais da respectiva entidade religiosa. Para a autora, apenas as atividades propriamente religiosas seriam preservadas da atividade fiscal do Estado ${ }^{7}$.

Coerentemente, a mesma autora critica a posição adotada pelo STF no RE n. 325.822, que teria estendido a imunidade tributária aos imóveis de propriedade da entidade religiosa, locados a terceiros, desde que os valores assim obtidos fossem empregados em suas finalidades essenciais. Para a autora, a interpretação mais adequada, considerando a diferença entre “imunidade-promoção" e “imunidade-proteção”, permitiria afastar-se a tributação dos valores obtidos com o dízimo, as doações e os serviços religiosos, mas não com imóveis alugados, rendas do mercado financeiro e comércio de bens não essenciais.

A posição prevalecente entre os doutrinadores, contudo, é mais aberta. Com base na proposta de isonomia entre todas as religiões, Sacha Calmon Navarro Coêlho sustenta que o conceito de templo compreenderia a catedral católica, a sinagoga, a casa espírita kardecista, o terreiro de candomblé ou de umbanda, a igreja protestante, shintoísta ou budista e a mesquita maometana, pouco importando a quantidade de adeptos ${ }^{8}$. Roque Antônio Carrazza ainda inclui nesse rol a loja maçônica, a Igreja da Razão (Igreja Positivista) e o centro espírita9.

De acordo com a doutrina majoritária no Brasil, o fundamento da imunidade tributária dos templos de qualquer culto (CF, art. 150, VI, 'b'), fortemente associada à ideia de liberdade,

\footnotetext{
${ }^{5}$ Quanto à definição de templo, citando os dicionários Aurélio e Michaelis, como também De Plácido e Silva, sinteticamente, Marton define templo como "o edifício onde se pratica culto religioso" (op. cit., p. 15), concluindo, a partir daí, que o projeto constitucional originário consistia em estabelecer regra de imunidade objetiva aos "templos de qualquer culto", não imunidade subjetiva às organizações religiosas.

${ }^{6}$ ÁVILA, Fabiana. A imunidade tributária dos templos de qualquer culto. Revista da FESDT. Porto Alegre, n. 6, p. 43-63, jul./dez. 2010. p. 49.

7 ÁVILA, Fabiana. A imunidade tributária dos templos de qualquer culto. Revista da FESDT. Porto Alegre, n. 6, p. 43-63, jul./dez. 2010. p. 57.

${ }^{8}$ COÊLHO, Sacha Calmon Navarro. Curso de direito tributário. 17. ed. Rio de Janeiro: Forense, 2020. Ebook. pos. 325.

9 CARRAZZA, Roque Antônio. Curso de direito constitucional tributário. 29. ed. São Paulo: Malheiros, 2013. p. 858.
} 
aloja-se na proteção e garantia da liberdade religiosa ${ }^{10}$ e na proteção dos valores espirituais. Nessa linha de pensamento, para Ricardo Lobo Torres, a "imunidade se estende ao patrimônio, à renda e aos serviços vinculados às finalidades essenciais do templo, o que exclui do seu manto protetor os impostos incidentes sobre a produção e a circulação de riquezas (IPI, ICMS)"11.

Em resumo, a imunidade tributária dos templos de qualquer culto encontram determinados lineamentos a partir da doutrina. Em primeiro lugar, a despeito da compreensão de que templo é o lugar em que se realiza o culto, a imunidade não se restringe ao lugar, prédio ou edificação, estendendo-se aos respectivos anexos, ainda que desprendidos da sede. 0 culto deve ser compreendido como conjunto de rituais pertinentes a determinada religião, de modo que "qualquer culto" seria, na verdade, "qualquer culto religioso". Considerando que a organização religiosa possa ter fontes de receita para aplicação em suas finalidades essenciais, o resultado econômico dessas fontes estaria, para a maioria da doutrina, abrangido pela imunidade.

\section{ANÁLISE DOS JULGADOS DO STF SOBRE A MATÉRIA}

No presente tópico, procuraremos inicialmente descrever nosso procedimento de investigação e individualizar o dispositivo metodológico que nos permitiu chegar aos achados de pesquisa adiante relatados, os quais nos forneceram os subsídios necessários às conclusões formuladas ao final do trabalho.

Conforme afirmado nas linhas introdutórias, optamos por utilizar uma base de dados conhecida e acessível, conferindo ao procedimento de composição do corpus os atributos da repetibilidade e, quanto possível, da objetividade. Considerando a importância do conceito de religião para uma nação multicultural como a brasileira, a relevância da atuação do Supremo Tribunal Federal como cúpula do poder judiciário brasileiro e órgão de uniformização da jurisprudência em matéria constitucional, selecionamos a temática do conceito de religião no STF como objeto de pesquisa para o presente trabalho. Finalmente, levando em conta a

10 "O fundamento da imunidade é a liberdade religiosa. No Estado Patrimonial luso-brasileiro apenas a Igreja Católica era imune. No Estado Fiscal a imunidade se estendeu a todos os cultos, tendo em vista que a liberdade de religião se transformou em um dos pilares do liberalismo. De modo que a interpretação do conceito de religião deve ser o mais ampla possível, para agasalhar também as religiões das minorias" (TORRES, Ricardo Lobo. Curso de direito financeiros e tributário. 18. ed. Rio de Janeiro: Renovar, 2011. p. 74).

11 TORRES, Ricardo Lobo. Curso de direito financeiros e tributário. 18. ed. Rio de Janeiro: Renovar, 2011. p. 74. 
ISSN 1981-3694

(DOI): $10.5902 / 1981369435079$

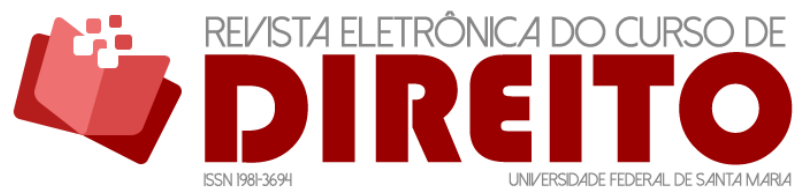

A IMUNIDADE TRIBUTÁRIA DOS TEMPLOS E O CONCEITO DE RELIGIÃO NO SUPREMO TRIBUNAL FEDERAL

ROGÉrIO ROBERTO GONÇALVES DE ABREU HÉLIO SILVIO OURÉM CAMPOS VIRGÍNIA COLARES

necessidade de um corte para maior individualização da amostra a ser pesquisada, optamos por considerar apenas as decisões do STF que cuidassem da imunidade tributária dos templos de qualquer culto, reunindo, dessa forma, no mesmo cenário, o papel do STF e o conceito de religião.

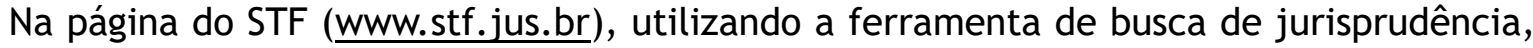
inserimos a seguinte chave de pesquisa no espaço de pesquisa livre: <(imunidade adj2 tributária) e religi\$>. Dessa forma, pesquisamos todos os julgados disponíveis nessa base de dados que reunissem, em conjunto, as expressões "imunidade tributária", de um lado, e "religião", "religioso", "religiosa" e demais derivados, de outro ${ }^{12}$. A caixa que autorizava a busca de julgados anteriores a 1950 não foi marcada. Com tais parâmetros de pesquisa, encontramos 26 acórdãos, 241 decisões monocráticas, uma decisão de repercussão geral e 12 informativos. Considerando os limites da pesquisa e a proposta de trabalharmos com decisões colegiadas do tribunal, optamos por considerar apenas os acórdãos (incluindo a repercussão geral) na análise empírica qualitativa.

Os acórdãos encontrados foram os seguintes: 01) ARE 1026335 AgR, Rel. Min. Marco Aurélio, Primeira Turma, julgado em 29 maio 2018'3; 02) ARE 1006235 AgR, Rel. Min. Edson Fachin, Segunda Turma, julgado em 24 mar. 20174; 03) RE 330817, Rel. Min. Dias Toffoli, Tribunal Pleno, julgado em 08 mar. 2017'15; 04) RE 595676, Rel. Min. Marco Aurélio, Tribunal Pleno, julgado em 08 mar. 2017'16; 05) ARE CAGR 898896 AgR-EDv-AgR, Rel. Min. Dias Toffoli, Tribunal Pleno, julgado em 24/02/201717; 06) RE 566622, Rel. Min. Marco Aurélio, Tribunal Pleno, julgado em 23 fev. 2017'18; 07) RE 608872, Rel. Min. Dias Toffoli, Tribunal Pleno, julgado em 23 fev.

\footnotetext{
12 Procedimento realizado, pela última vez, em 12 set. 2018.

13 O tribunal, em agravo, manteve decisão monocrática do relator que não conheceu o RE sob o fundamento de que a questão fora decidida no âmbito infralegal, não servindo a via eleita para rediscutir fatos e provas nem matéria infraconstitucional.

${ }^{14} \mathrm{O}$ tribunal não conheceu o RE sob o fundamento de que o concreto preenchimento dos requisitos para a titularidade da imunidade seria matéria de fato, sendo a distribuição dinâmica dos ônus da prova matéria infraconstitucional.

${ }^{15}$ A demanda dizia respeito à extensão da imunidade dos livros aos livros eletrônicos e e-readers, ou seja, leitores de livros eletrônicos.

${ }^{16} \mathrm{~A}$ demanda dizia respeito à imunidade dos componentes eletrônicos dos e-readers.

17 O tribunal não conheceu o RE sob o fundamento de que, em relação a determinado imóvel de entidade religiosa, a análise do preenchimento dos requisitos para a imunidade dependeria do revolvimento de fatos e provas.

$18 \mathrm{O}$ tribunal decidiu que apenas por lei complementar seria possível disciplinar imunidades tributárias. A demanda envolvia sociedade beneficente de assistência social e o INSS, questionando a primeira a constitucionalidade de norma da Lei n. 8.212/91 que estabelecia requisitos para o gozo de imunidade em relação a contribuições sociais.
} 
$2017^{19}$; 08) ARE 900676 ED-AgR, Rel. Min. Luiz Fux, Primeira Turma, julgado em 23 set. 2016 ${ }^{20}$; 09) ARE CAGR 915011 AgR, Rel. Min. Celso de Mello, Segunda Turma, julgado em 10 nov. 201521; 10) ARE CAGR 898896 AgR, Rel. Min. Dias Toffoli, Segunda Turma, julgado em 27 out. 2015²2; 11) ARE 861950 AgR, Rel. Min. Marco Aurélio, Primeira Turma, julgado em 19 maio 2015²3; 12) ARE CAGR 866402 AgR, Rel. Min. Celso de Mello, Segunda Turma, julgado em 24 mar. 201524; 13) ARE CAGR 788666 AgR, Rel. Min. Roberto Barroso, Primeira Turma, julgado em 10 fev. 2015'25; 14) ARE CAGR 841212 AgR, Rel. Min. Luiz Fux, Primeira Turma, julgado em 18 nov. 201426; 15) ARE CAGR 800395 AgR, Rel Min. Roberto Barroso, Primeira Turma, julgado em 28 out. 2014 ${ }^{27}$; 16) ADI 429, Rel. Min. Luiz Fux, Tribunal Pleno, julgado em 20 ago. 2014 ${ }^{28}$; 17) ARE CAGR 790299 AgR, Rel. Min. Gilmar Mendes, Segunda Turma, julgado em 20 maio $2014^{29}$; 18) ARE CAGR 694453 AgR, Rel.

${ }^{19}$ A demanda dizia respeito a imunidade tributária de entidades de assistência social em relação ao ICMS de mercadorias adquiridas no mercado interno, afirmando-se contribuintes de fato.

20 O tribunal reconheceu a entidade religiosa a imunidade tributária, como contribuinte de direito, em relação ao recolhimento de ICMS. Afirmou a presunção de destinação do patrimônio, da renda e dos serviços às finalidades essenciais das entidades imunes, cabendo ao fisco provar eventual desvio de finalidade.

${ }^{21} \mathrm{O}$ tribunal negou provimento ao agravo sob o fundamento de que a decisão recorrida estava em sintonia com a jurisprudência do tribunal, no sentido de reconhecer a extensão da imunidade tributária às dependências do templo que servem de residência do ministro religioso. Citou, como precedente, o ARE 694.453-AgR/DF.

${ }^{22} \mathrm{O}$ tribunal não conheceu o RE sob o fundamento de que, em relação a determinado imóvel de entidade religiosa, a análise do preenchimento dos requisitos para a imunidade dependeria do revolvimento de fatos e provas.

${ }^{23}$ Tratava-se de recurso do município do Rio de Janeiro contra decisão que havia reconhecido imunidade tributária a entidade religiosa. 0 tribunal não conheceu o RE sob o fundamento de que, para afastar o entendimento de que o imóvel, no caso concreto, servia às finalidades essenciais da entidade religiosa, teria que reexaminar fatos e provas.

$24 \mathrm{O}$ tribunal negou provimento ao agravo sob o fundamento de que a decisão recorrida estava em sintonia com a jurisprudência do tribunal, no sentido de não reconhecer a extensão da imunidade tributária dos templos às lojas maçônicas. Citou, como precedente, o RE 562.351/RS.

${ }^{25} \mathrm{O}$ tribunal negou provimento ao agravo e manteve a decisão que negou seguimento a RE sob o fundamento de que o exame da destinação concreta do imóvel de entidade religiosa demandaria o revolvimento de fatos e provas. A ementa registra a expressão "imóvel em obras".

${ }^{26} \mathrm{O}$ tribunal reafirmou a presunção de que os imóveis de entidade religiosa destinam-se ao cumprimento de suas finalidades essenciais, cabendo ao fisco provar eventual desvio de finalidade. Afirmou ainda que o exame dessa tredestinação exigiria o revolvimento de fatos e provas.

270 tribunal reafirmou a tese segundo a qual não cabe à entidade religiosa demonstrar a vinculação da destinação do bem imóvel de sua propriedade a suas finalidades essenciais, mas, ao fisco, a tredestinação do bem. A decisão se referia a terrenos não edificados de entidade religiosa, os quais, segundo o tribunal, estariam compreendidos na imunidade.

${ }^{28}$ O tribunal declarou a inconstitucionalidade de dispositivos da Constituição do Estado do Ceará que tratavam de matéria tributária, notadamente sobre a disciplina do ICMS.

${ }^{29}$ A demanda dizia respeito a pedido de Loja Maçônica de aplicação da imunidade tributária dos templos de qualquer culto, argumentando que a redação da Constituição Federal não previa a natureza religiosa do culto como condição para a imunidade. Reafirmando a própria jurisprudência, o tribunal registrou a necessidade da natureza religiosa do culto. Como precedentes, citou o Al 690712, o RE 578.562 e, com 
Min. Ricardo Lewandowski, Segunda Turma, julgado em 25 jun. 2013 ${ }^{30}$; 19) ARE CAGR 715034 AgR, Rel. Min. Marco Aurélio, Primeira Turma, julgado em 07 maio 2013 31; 20) ARE 663839 AgR, Rel. Min. Marco Aurélio, Primeira Turma, julgado em 18 dez. 2012 ${ }^{32}$; 21) ARE CAGR 655042 AgRsegundo, Rel. Min. Carmen Lúcia, Segunda Turma, julgado em 30 out. 201233; 22) RE 562351, Rel Min. Ricardo Lewandowski, Primeira Turma, julgado em 04 set. 2012 ${ }^{34}$; 23) ARE CAGR 658080 AgR, Rel. Min. Luiz Fux, Primeira Turma, julgado em 13 dez. 201135; 24) ARE 601927 AgR, Rel. Min. Celso de Mello, Segunda Turma, julgado em 13 set. 201136; 25) RE 578562, Rel. Min. Eros Grau, Tribunal Pleno, julgado em 21 maio 200837; 26) RE 325822, Rel. Min. Ilmar Galvão, Rel. p/ acórdão: Min. Gilmar Mendes, Tribunal Pleno, julgado em 18 dez. 2002 ${ }^{38}$. 0 acórdão de repercussão geral foi proferido nos autos do RE 630790 RG, Rel. Min. Joaquim Barbosa, julgado em 21 out. $2010^{39}$.

Analisando os fundamentos de cada um dos julgados acima, chegamos à seguinte classificação:

A) Destinação presumida do patrimônio, renda e serviços às finalidades essenciais da entidade religiosa (cemitério, residência do ministro religioso);

destaque, o RE 562.351, examinando matéria idêntica. Por fim, assentou que o exame das atividades concretamente realizadas pela entidade envolveria matéria de fato não afeta aos limites do RE.

30 O tribunal decidiu que a imunidade tributária dos templos de qualquer culto se aplicaria ao imóvel destinado à residência do ministro religioso.

31 O tribunal não conheceu o RE sob o fundamento de que o exame sobre a concreta destinação do imóvel às finalidades essenciais de entidade religiosa exigiria o revolvimento de fatos e provas.

32 O tribunal não conheceu o RE sob o fundamento de que o exame sobre a concreta destinação do imóvel às finalidades essenciais de entidade religiosa exigiria o revolvimento de fatos e provas.

${ }^{33} \mathrm{O}$ tribunal não conheceu o RE sob o fundamento de que o exame sobre a concreta destinação de imóvel às finalidades essenciais de entidade religiosa exigiria o revolvimento de fatos e provas.

${ }^{34} \mathrm{O}$ tribunal decidiu que a expressão "templos de qualquer culto" não compreenderia as lojas maçônicas, assentando que a "imunidade tributária conferida pelo art. 150, VI, $b$ é restrita aos templos de qualquer culto religioso, não se aplicando à maçonaria, em cujas lojas não se professa qualquer religião".

${ }^{35}$ Conquanto seja claro que trate de imunidade tributária a imóveis destinados a finalidades essenciais e se fundamente na CF, art. 150, VI, $b$ e $c$, o acórdão ora se refere a entidade beneficente, ora a entidade religiosa. Reafirmando sua jurisprudência, o tribunal decidiu pela imunidade tributária inclusive aos imóveis vagos da respectiva entidade, sendo presumida a destinação às finalidades essenciais.

${ }^{36} \mathrm{O}$ tribunal não conheceu o RE sob o fundamento de que a discussão impunha o revolvimento de fatos e provas.

$37 \mathrm{O}$ tribunal decidiu que a imunidade tributária dos templos de qualquer culto se estenderia ao cemitério anexo à entidade religiosa.

380 tribunal decidiu que a imunidade dos templos de qualquer culto se estenderia aos imóveis de propriedade da entidade religiosa alugados a terceiros. Por maioria, a Corte entendeu que os valores assim obtidos seriam presumivelmente aplicados nas finalidades essenciais da organização religiosa.

39 O tribunal reconheceu a existência de repercussão geral da discussão sobre a caracterização, como assistência social, de atividade filantrópica executada à luz de preceitos religiosos, bem como sobre a extensão da correlativa imunidade ao imposto de importação. 
B) Extensão da imunidade tributária em relação a imóveis não utilizados (terrenos vagos, imóveis em construção);

C) Necessidade do reexame de fatos e provas (súmula 279/STF) ou de legislação infraconstitucional (comprovação do desempenho de atividade religiosa no caso concreto);

D) Imunidade tributária a entidade beneficente de assistência social;

E) Temas alheios à imunidade tributária dos templos de qualquer culto (imunidade de livros eletrônicos, inconstitucionalidade de normas constitucionais estaduais sobre ICMS);

F) Caráter religioso de entidades que pleiteiam o reconhecimento da imunidade tributária (maçonaria).

Como foi possível observar, a partir dos parâmetros de pesquisa utilizados, a ferramenta de busca da página do Supremo Tribunal Federal na internet exibiu diversas decisões não pertinentes ao tema da imunidade tributária dos templos de qualquer culto. Apesar de o texto do acórdão conter os vocábulos de pesquisa, o tema objeto da decisão se relacionava a assuntos diversos da imunidade aqui examinada. Esses julgados formam a totalidade dos grupos $D$ e $E$, além de parte do grupo $C$, com destaque para a temática da imunidade das entidades de assistência social prevista no art. 150, VI, 'c', da CF/88.

Os acórdãos que compõem os grupos A, B e F, além da parte do grupo C não mencionada no parágrafo anterior, referem-se a decisões do Supremo Tribunal Federal em processos nos quais se discutia o reconhecimento da imunidade tributária dos templos de qualquer culto (CF, art. 150, VI, 'b') em litígios tributários entre entidades alegadamente religiosas e entes da Fazenda Pública. Em parcela significativa desses julgados, o STF não decidiu o mérito do recurso constitucional interposto, afirmando que o enfrentamento da questão do concreto desempenho de atividade religiosa no caso concreto, como matéria de fato, demandaria do tribunal o reexame de provas, procedimento que infringiria a orientação da Súmula 279/STF. Nesses casos, o STF não conheceu o recurso extraordinário ou negou provimento ao agravo interposto contra a decisão monocrática do relator que the negava seguimento.

Excluídos os acórdãos referidos nos dois parágrafos anteriores, temos, finalmente, casos em que o Supremo Tribunal Federal, direta ou indiretamente ${ }^{40}$, decidiu sobre a extensão da imunidade tributária dos templos de qualquer culto, reconhecendo ou não sua titularidade e aplicação ao litigante particular no caso concreto. Ainda assim, podemos dizer que as

40 Dizemos "direta ou indiretamente" porque reconhecemos que, naqueles casos em que o STF não conheceu o recurso extraordinário ou negou provimento ao agravo contra a decisão que the negava seguimento sob o fundamento de que a decisão recorrida estava em sintonia com a jurisprudência já firmada pelo próprio STF, o tribunal termina se manifestando sobre o mérito da causa, embora sem conhecer a pretensão recursal. 
controvérsias conhecidas e debatidas pelo STF nesses julgamentos se restringiam (i) à presunção de destinação do patrimônio, da renda e dos serviços das entidades religiosas a suas finalidades essenciais, (ii) à aplicação da imunidade em relação a tributos incidentes sobre imóvel ainda não utilizado pela entidade religiosa proprietária e, finalmente, (iii) à configuração ou não do caráter religioso da entidade litigante.

0 que nos chamou a atenção a partir do exame das peças que compõem o inteiro teor desses julgados foi o aspecto de que, apesar de decidir sobre a aplicação da imunidade destinada aos templos de qualquer culto, de exigir do culto em questão o caráter ou a natureza religiosa e, finalmente, de reconhecer e negar direitos com base nessa exigência, o Supremo Tribunal Federal jamais estabeleceu, de forma precisa e em decisão colegiada, o que deva ou possa ser compreendido como religião ou religioso. Em outras palavras, diz o STF que, para merecer a imunidade do art. 150, VI, 'b', da CF/88, a entidade deve ser religiosa e seus cultos devem ser religiosos, mas não define, com a necessária precisão, o que, afinal, configura essa natureza ou esse caráter religioso dos cultos e das entidades.

Nesse aspecto, há uma diferença, no âmbito da linguagem, entre os julgados dos grupos A e $B$, de um lado, e do grupo $F$, de outro. Os primeiros lidam com pretensões à aplicação da imunidade tributária dos templos de qualquer culto a partir de uma compreensão naturalizada de religião, de modo que a discussão sobre o que seja ou não religioso simplesmente não existe, já que, ao que parece, todos sabem o que é religião ou religioso ${ }^{41}$. A ideia de religião, portanto, surge como integrada ao senso comum teórico dos julgadores ${ }^{42}$, de modo que a ausência de

\footnotetext{
41 John B. Thompson (Ideologia e cultura moderna: teoria social crítica na era dos meios de comunicação de massa. 9. ed. Petrópolis, RJ: Vozes, 2011. p. 81 ss.) trabalha cinco modos gerais de operação de ideologia, abordando ainda algumas das estratégias típicas de construção simbólica respectivamente aplicáveis a cada um deles. De acordo com o autor, através da reificação é possível estabelecer e sustentar relações de dominação pela retratação de uma situação transitória ou histórica (i.e., de surgimento e/ou existência historicamente situada) como permanente, natural, atemporal. As estratégias simbólicas de reificação apresentadas são a naturalização, por meio de que criações sociais e históricas são retratadas como eventos naturais ou o mero resultado de características naturais, e a eternalização, com fenômenos históricos sendo apresentados como permanentes e imutáveis.

42 Luiz Alberto Warat (Introdução geral ao direito I: Interpretação da lei: temas para uma reformulação. Porto Alegre: Sergio Antonio Fabris Editor, 1994) escreve que, "De uma maneira geral, a expressão 'senso comum teórico dos juristas' designa as condições implícitas de produção, circulação e consumo das verdades nas diferentes práticas de enunciação e escritura do Direito. Trata-se de um neologismo proposto para que se possa contar com um conceito operacional que sirva para mencionar a dimensão ideológica das verdades jurídicas" (p. 13). Com essa abertura, o autor descreve e critica o emprego ideológico da linguagem na formação das verdades jurídicas produzidas, distribuídas e consumidas no âmbito das instituições de operação jurídica, ocultando, sob a máscara da objetividade de definições e explicações, o papel que apresentam as relações de poder decorrentes de seu lugar de fala e do papel que desempenha na sociedade. Resumindo, diz Warat, "os juristas contam com um emaranhado de costumes intelectuais que são aceitos como verdades de princípios para ocultar o componente político da investigação de
} 
ISSN 1981-3694

(DOI): $10.5902 / 1981369435079$

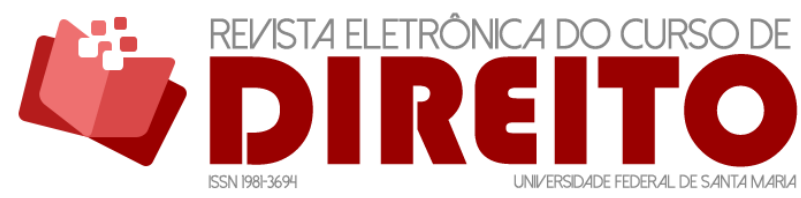

A IMUNIDADE TRIBUTÁRIA DOS TEMPLOS E O CONCEITO DE RELIGIÃO NO SUPREMO TRIBUNAL FEDERAL

ROGÉrio ROBERTO GONÇALVES DE ABREU HÉLIO SILVIO OURÉM CAMPOS VIRGÍNIA COLARES

dúvida afasta a necessidade de se empreender qualquer esforço em levantar a discussão. As entidades são religiosas, seus cultos são religiosos. Ponto final ${ }^{43}$.

Quanto aos julgados do grupo F, já não identificamos essa calmaria conceitual. Nesses casos - como um estágio, uma fase necessária ao posterior reconhecimento da imunidade tributária dos templos de qualquer culto - entidades pleiteiam, alternativamente, o reconhecimento de seu caráter religioso ou a desnecessidade da natureza religiosa dos cultos por elas conduzidos, de modo que em discussão está o próprio conceito de religião. Apenas três julgados se enquadram nessa moldura, sendo que dois deles (ARE CAGR 866402 AgR e ARE CAGR 790299 AgR) apenas reafirmam a jurisprudência estabelecida pelo tribunal a partir do paradigma firmado com o RE 562351, de relatoria do ministro Ricardo Lewandowski, julgado pela Primeira Turma em 04 set. 2012.

É esse julgado que analisamos no tópico seguinte.

\section{JULGADO PARADIGMA: RE 562.351/RS}

Inicialmente, é preciso frisar que o campo de análise da ciência jurídica é, para Kelsen, bastante restrito.

O Recurso Extraordinário n. 562.351/RS ${ }^{44}$ teve seu julgamento na Primeira Turma do STF iniciado em 13 abr. 2010, com a relatoria do ministro Ricardo Lewandowski. No relatório, o relator registrou tratar-se de recurso interposto pela Loja Maçônica Grande Oriente do Rio Grande do Sul contra acórdão que the negou a imunidade tributária prevista no art. 150, VI, alíneas ' $b$ ' e ' $c$ ', da Constituição Federal. Na origem, o demandante pretendia afastar, em embargos à execução fiscal, a cobrança de IPTU pelo município de Porto Alegre/RS.

O debate foi suspenso em razão de pedido de vista pelo ministro Marco Aurélio de Mello, que trouxe os autos para continuação em 04 set. 2012, apresentando seu voto-vista em sentido

verdades. Por conseguinte se canonizam certas imagens e crenças para preservar o segredo que escondem as verdades. 0 senso comum teórico dos juristas é o lugar do secreto. As representações que o integram pulverizam nossa compreensão do fato de que a história das verdades jurídicas é inseparável (até o momento) da história do poder" (p. 15).

${ }^{43}$ É importante registrar que a fundamentação dos julgados referidos no presente trabalho simplesmente não refere qualquer outra decisão do mesmo tribunal, monocrática ou colegiada, que tenha se empenhado em definir religião. Esse particular aspecto empiricamente constatado nos sugere que a opção metodológica de formação do corpus a partir da base de dados do sítio do STF na internet não implica negligenciar possíveis julgados que infirmassem as conclusões da pesquisa.

${ }^{44}$ BRASIL. Supremo Tribunal Federal (1. Turma). Recurso Extraordinário n. 562.351/RS. Relator: Min. Ricardo Lewandowski, 04 set. 2012, publicado em 14 dez. 2012. Disponível em: http://redir.stf.jus.br/paginadorpub/paginador.jsp?docTP=TP\&docID=3195619. Acesso em: 04 jun. 2020. 
divergente da maioria já formada. Nessa data, foi proferido o resultado. A seguir, examinaremos o caminho que tomou o STF em julgamento que se tornou, afinal, paradigmático.

\subsection{0 voto impresso do relator}

Como à ciência jurídica, de um modo geral, cabe apenas conhecer e descrever essa plurissignificação, aos penalistas, em particular, cabe dizer que, em se tratando de direito penal, as palavras devem ter essa relativa indeterminação de sentido reduzida ao máximo.

Inicialmente, com base na súmula 279/STF, o relator votou pelo não conhecimento do RE com relação ao art. 150, VI, 'c', da CF/88, eis que demandaria o revolvimento de fatos e provas, atividade alheia ao alcance do recurso. Na sequência, passou a fundamentar sua decisão sobre a pretensão de imunidade com base no art. 150, VI, 'b', da CF/88, destinada aos templos de qualquer culto e, já no início, fixou o que the pareceu a controvérsia a dirimir: "A questão central está, então, em saber se a expressão 'templos de qualquer culto' alcança a maçonaria" 45 .

O relator começa sua fundamentação com a seguinte transcrição:

Segundo ensina Sacha Calmon Navarro Coelho

'Templo, do latim templum, é o lugar destinado ao culto. Em Roma era lugar aberto, descoberto e elevado, consagrado pelos augures, sacerdotes da adivinhação, a perscrutar a vontade dos deuses, nessa tentativa de todas as religiões de religar o homem e sua finitude ao absoluto, a Deus. Hoje, os templos de todas as religiões são comumente edifícios (...).

Onde quer que se oficie um culto, aí é o templo. No Brasil, o Estado é laico. Não tem religião oficial. A todas respeita e protege, não indo contra as instituições religiosas com o poder de polícia ou o poder de tributar (...).

O templo, dada a isonomia de todas as religiões, não é só a catedral católica, mas a sinagoga, a casa espírita kardecista, o terreiro de candomblé ou de umbanda, a igreja protestante, shintoísta ou budista e a mesquita maometana. Pouco importa tenha a seita poucos adeptos. Desde que uns na sociedade possuam fé comum e se reúnam em lugar dedicado exclusivamente ao culto da sua predileção, este lugar há de ser um templo e gozará de imunidade tributária' (grifei $^{46}$ [grifos no original].

\footnotetext{
45 Voto do relator, p. 2.

${ }^{46}$ Voto do relator, p. 2-3.
} 
O relator transcreve a passagem acima da obra do professor Sacha Calmon Navarro Coelho e, assim fazendo, incorpora-lhe o conteúdo a seu processo de tomada de decisão, de modo que precisamos examiná-la para descobrir o que traz em termos de reforço de argumentação à tese apresentada pelo ministro logo em seguida.

No primeiro parágrafo, o autor ${ }^{47}$ vincula os conceitos de 'templo' e de 'culto' em uma relação instrumental (o templo como o lugar em que se realiza o culto), envolvendo ainda os conceitos de 'sacerdote' e 'deuses', aparecendo desde já a tonalidade religiosa do conceito que começa a delinear. Logo em seguida, o autor propõe uma conexão entre o culto e a proposta "de todas as religiões de religar o homem e sua finitude ao absoluto, a Deus", implicando entender que o sentido do culto estaria em fazer a ponte entre o homem finito e o Deus infinito, generalizando a ideia como se fosse aplicável a todas as religiões.

O culto, portanto, não apenas é e tem que ser religioso, mas também se dirige a um Deus infinito e absoluto. Em sua opinião, o templo seria o lugar em que tudo isso acontece e o autor encerra o parágrafo afirmando a relação de pertinência entre templo e religião ("os templos de todas as religiões").

A estrita vinculação funcional e instrumental entre o templo e o culto inicia o segundo parágrafo. Registra-se ali a natureza laica do Estado brasileiro, dizendo-se o que significa em termos negativos (não ter religião oficial) e positivos (a todas protegendo). No contexto em que define culto e templo, a ideia de religião é uma constante no texto, que assim revela ainda uma vez sua compreensão de culto como 'culto religioso'.

No terceiro parágrafo, sem perder de vista a 'relação templo-culto-religião', o autor ${ }^{48}$ procura identificar espécies de religiões cujos lugares de culto seriam considerados templos, tomando o cuidado de mostrar que todas - não apenas as de maior adesão no Brasil - estariam credenciadas à imunidade tributária. Na parte final do parágrafo, salientando o caráter isonômico do favor constitucional, aponta, como requisitos mínimos para a imunidade, a existência de alguma quantidade de pessoas que tenha a mesma fé e a circunstância de que tais

${ }^{47}$ COELHO, Sacha Calmon Navarro. Comentários à Constituição de 1988 - Sistema Tributário. 10. ed. Rio de Janeiro: Forense, 2006, pp. 331-332 apud BRASIL. Supremo Tribunal Federal (1. Turma). Recurso Extraordinário n. 562.351/RS. Relator: Min. Ricardo Lewandowski, 04 set. 2012, publicado em 14 dez. 2012. Disponível em: http://redir.stf.jus.br/paginadorpub/paginador.jsp?docTP=TP\&docID=3195619. Acesso em: 04 jun. 2020.

${ }^{48}$ COELHO, Sacha Calmon Navarro. Comentários à Constituição de 1988 - Sistema Tributário. 10. ed. Rio de Janeiro: Forense, 2006, pp. 331-332 apud BRASIL. Supremo Tribunal Federal (1. Turma). Recurso Extraordinário n. 562.351/RS. Relator: Min. Ricardo Lewandowski, 04 set. 2012, publicado em 14 dez. 2012. Disponível em: http://redir.stf.jus.br/paginadorpub/paginador.jsp?docTP=TP\&docID=3195619. Acesso em: 04 jun. 2020. 
pessoas se reúnam em determinado lugar exclusivamente dedicado ao culto dessa fé: nesse caso, o lugar assim destinado com exclusividade será um templo para fins de imunidade tributária.

Entre os exemplos de religião cujos locais de culto seriam imunes, Sacha Calmon Navarro Coelho ${ }^{49}$ cita o budismo, para o qual os deuses têm um papel muito diferente daquele atribuído pelas religiões propriamente teístas, pois o culto budista focaliza as relíquias de Buda, que não era um deus ${ }^{50}$. De certa forma, isso parece contradizer o conteúdo do primeiro parágrafo. Essa contradição presente no próprio seio do discurso relatado ${ }^{51}$ sugere que a ideia de religião textualmente construída refletiria antes a opinião ou o senso comum do julgador (doxa) que o resultado de uma pesquisa específica sobre o tema (episteme). Registre-se ainda que, nessa construção, o ministro destacou todas as variações da palavra religião na passagem que transcreveu.

O relator prosseguiu sua fundamentação em novo discurso relatado, também aqui grifando todas as variações da palavra religião:

Já Roque Antonio Carraza afirma que

"Esta imunidade, em rigor, não alcança o templo propriamente dito, isto é, o local destinado a cerimônias religiosas, mas, sim, a entidade mantenedora do templo, a igreja.

[...]

É fácil percebermos que esta alínea 'b' visa a assegurar a livre manifestação da religiosidade das pessoas, isto é, a fé que elas têm em certos valores transcendentais. As entidades tributantes não podem, nem mesmo por meio de impostos, embaraçar o exercício de cultos religiosos" (grifos nossos) ${ }^{52}$.

De acordo com o que está escrito no primeiro parágrafo, o "templo propriamente dito" é o "local destinado a cerimônias religiosas": não qualquer cerimônia, mas apenas aquelas que

\footnotetext{
${ }^{49}$ COELHO, Sacha Calmon Navarro. Comentários à Constituição de 1988 - Sistema Tributário. 10. ed. Rio de Janeiro: Forense, 2006, pp. 331-332 apud BRASIL. Supremo Tribunal Federal (1. Turma). Recurso Extraordinário n. 562.351/RS. Relator: Min. Ricardo Lewandowski, 04 set. 2012, publicado em 14 dez. 2012. Disponível em: http://redir.stf.jus.br/paginadorpub/paginador.jsp?docTP=TP\&doclD=3195619. Acesso em: 04 jun. 2020.

${ }^{50}$ Cf. LAMBERT, Yves. 0 nascimento das religiões: da pré-história às religiões universalistas. São Paulo: Edições Loyola, 2011. p. 465 ss. e GAARDER, Jostein; HELLERN, Victor; NOTAKER, Henry. 0 livro das religiões. Tradução Isa Mara Lando. São Paulo: Companhia das Letras, 1989 [copyright]. E-book. Locais do Kindle 1117-1118 e ss.

${ }^{51}$ Sobre discurso relatado, cf. RESENDE, Viviane de Melo, RAMALHO, Viviane. Análise de discurso crítica. 2. ed., São Paulo: Contexto, 2017, p. 65 ss. e FAIRCLOUGH, Norman. Discurso e mudança social. 2. ed. Brasília: Editora Universidade de Brasília, 2016 [1992], p. 158 ss.

52 Voto do relator, p. 3.
} 
tenham caráter religioso, ainda que o voto não registre o que significa "ser religioso" para o autor nele citado. Consta ainda que a imunidade seria titularizada pela entidade mantenedora do templo, que identifica como "igreja"53.

No segundo parágrafo, o autor ${ }^{54}$ emprega uma construção frasal que nos permite identificar o esboço da formulação de um conceito: "religiosidade é a fé que as pessoas têm em certos valores transcendentais". Além disso, vemos que, para ele, os conceitos de religiosidade, religião, fé, valores (transcendentais) e cultos (religiosos) estão juntos, pertencendo a um mesmo contexto e, por isso, fazendo sentido quando visualizados em conjunto. 0 esboço, contudo, não evolui para uma verdadeira tentativa de definição.

Prosseguiu o ministro relator:

No julgamento do RE 578.562/BA, o Min. Eros Grau assentou que "O Supremo Tribunal Federal tem entendido que a limitação ao poder de tributar, que a imunidade do artigo 150, VI, 'b', contempla, há de ser amplamente considerada, de sorte a ter-se como cultos distintas expressões de crença espiritual" ${ }^{\prime 5}$.

Analisando-se apenas o pequeno trecho acima, vemos que o ministro Eros Grau associa os cultos referidos no dispositivo constitucional a "distintas expressões de crença espiritual”. No excerto, não há referência a deuses, nem à transcendência da alma ou mesmo a uma vida após a morte. Ainda examinando o RE 578.562/BA, o relator afirma que:

Vale destacar também o quanto concluiu o Min. Ayres Britto naquele julgamento: "tendo a interpretar a regra constitucional da imunidade sobre os templos de qualquer culto como uma espécie de densificação ou de concreção do inciso $\mathrm{VI}$ do art. $5^{\circ}$ da mesma Constituição, cuja dicção é esta:

'ART. $5^{\circ}$.

(...)

VI- é inviolável a liberdade de consciência e de crença, sendo assegurado o livre exercício dos cultos religiosos e garantida, na forma da lei, a proteção aos locais de cultos e as suas liturgias; (...)'

\footnotetext{
${ }^{53}$ Considerando que nem todo templo religioso se enquadra na definição de "igreja", o autor da passagem transcrita não deixa de revelar uma compreensão pessoal e restritiva de religião, incorporada aparentemente sem restrição à razão de decidir do relator.

${ }^{54}$ CARRAZA, Roque Antonio. Curso de Direito Constitucional Tributário. 23. ed. São Paulo: Malheiros, 2007, pp. 739-731 apud apud BRASIL. Supremo Tribunal Federal (1. Turma). Recurso Extraordinário n. 562.351/RS. Relator: Min. Ricardo Lewandowski, 04 set. 2012, publicado em 14 dez. 2012. Disponível em: http: / / redir.stf.jus.br/paginadorpub/paginador.jsp?docTP=TP\&docID=3195619. Acesso em: 04 jun. 2020.

55 Voto do relator, p. 3-4.
} 
Uma coisa, portanto, puxando a outra" ${ }^{56}$.

0 excerto transcrito do voto do min. Ayres Britto ilustra seu entendimento segundo o qual a imunidade aos templos seria uma "densificação" da proteção à "liberdade de consciência e de crença” e ao "livre exercício dos cultos religiosos”, de modo que os conceitos de 'templo', 'culto', 'consciência', 'crença' e 'liberdade' estariam reunidos na estrutura normativa que cria a referida garantia constitucional. O relator conclui dizendo que a imunidade se destina a proscrever eventuais embaraços ao exercício da liberdade de crença religiosa e a garantir o livre exercício desses cultos, excluindo a liberdade de consciência. Para fundamentar essa posição, recorre novamente a Carrazza:

Nas lições do já citado professor Carrazza, citado inclusive pelo recorrente para fundamentar sua pretensão:

"A imunidade em tela decorre, naturalmente, da separação entre Igreja e o Estado, decretada com a Proclamação da República.

Sabemos que, durante o Império, tínhamos uma religião oficial: a religião católica apostólica romana. As outras religiões eram toleradas, mas apenas a católica recebia especial proteção do Estado.

(...)

Muito bem, com a proclamação da República, que se inspirava no positivismo de Augusto Comte, foi imediatamente decretada a separação entre a Igreja e o Estado. O Estado tornou-se laico. Deixou de dispensar maior proteção a uma religião em particular (ainda que majoritária), para tolerar todas elas.

Evidentemente, o Estado tolera todas as religiões que não ofendem a moral, nem os bons costumes, nem, tampouco, fazem perigar a segurança nacional. Há, no entanto, uma presunção no sentido de que a religião é legítima, presunção, esta, que só cederá passo diante de prova em contrário, a ser produzida pelo Poder Público.

Graças a esta inteligência, tem-se aceito que também são templos a loja maçônica, o templo positivista e o centro espírita" (grifei).

Ora, em que pese o brilhantismo do raciocínio desenvolvido pelo eminente tributarista, entendo que a conclusão a que ele chega não pode prevalecer ${ }^{57}$.

A partir desse ponto, o relator passa a argumentar com a necessidade de se interpretar restritivamente as normas constitucionais definidoras de imunidades tributárias, opondo-as às normas constitucionais garantidoras das liberdades. Arremata o ponto dizendo que: "Nessa linha,

\footnotetext{
56 Voto do relator, p. 4.

57 Voto do relator, p. 5.
} 
ISSN 1981-3694

(DOI): $10.5902 / 1981369435079$

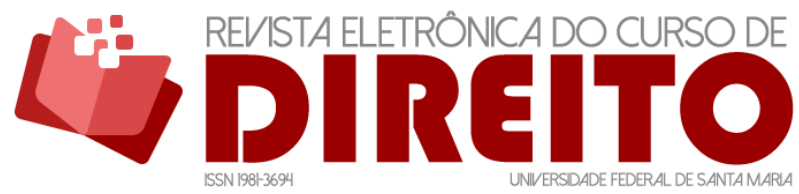

A IMUNIDADE TRIBUTÁRIA DOS TEMPLOS E O CONCEITO DE RELIGIÃO NO SUPREMO TRIBUNAL FEDERAL

ROGÉRIO ROBERTO GONÇALVES DE ABREU HÉLIO SILVIO OURÉM CAMPOS VIRGÍNIA COLARES

penso que, quando a Constituição conferiu imunidade tributária aos 'templos de qualquer culto', este benefício fiscal está circunscrito aos cultos religiosos" ${ }^{25}$.

Pois bem. 0 raciocínio do relator é o seguinte: as imunidades se restringem aos (templos de) cultos religiosos, motivo pelo qual a maçonaria não se enquadraria na regra de imunidade dos templos de qualquer culto. 0 argumento, contudo, ainda nos parece obscuro. Por que a maçonaria não seria imune em relação ao patrimônio, renda e serviços destinados a suas finalidades essenciais? Seria porque não há cultos na maçonaria? Seria porque, havendo cultos, não seriam religiosos? Seria porque, havendo cultos religiosos na maçonaria, mas, não sendo ela uma religião, não possuiria cultos religiosos próprios?

Em causa está, pois, a compreensão da corte sobre a prática de cultos religiosos no âmbito da maçonaria. Como o Supremo Tribunal Federal, em recurso extraordinário, não decide questões meritórias de fato, não nos parece admissível que a controvérsia se concentrasse na palavra "existência" (i.e., se havia ou não cultos). Partindo da admissão de que há cultos na maçonaria, o tribunal só poderia discutir a causa, sem violar sua súmula n. 279 , limitando-se à natureza religiosa do culto ali praticado e à exigibilidade do caráter religioso desse culto.

Caberia ao tribunal, diante disso, decidir dois pontos. Primeiro, se a Constituição Federal de 1988 exigia do culto celebrado no templo e da entidade que o conduzisse o caráter religioso. Segundo, se a entidade demandante e o culto por ela conduzido em suas dependências (que pretende denominar de templo) seriam ou não, de fato, religiosos. A primeira parte foi cumprida nas linhas acima, concluindo o relator que a imunidade se restringe aos "templos de qualquer culto religioso". Faltava discutir se a maçonaria e seus cultos preenchiam o requisito da religiosidade. Em qualquer caso, estaria inevitavelmente em jogo a própria ideia de religião.

Como é possível constatar do voto do relator, o ministro respondeu negativamente à segunda pergunta, fazendo-o, contudo, de forma implícita no primeiro momento para, em seguida, concluir pela inexistência de religiosidade na maçonaria e nos cultos por ela conduzidos. Em sua fundamentação, o relator não resolve o problema do que seja, afinal, religião. Antes, prefere limitar-se ao exame de texto colhido da página virtual da maçonaria e em trecho do acórdão recorrido, concluindo logo em seguida pelo improvimento do recurso. A transcrição seguinte, embora longa, encerra o voto, permitindo-nos uma análise mais acurada na sequência:

\footnotetext{
${ }^{58}$ Voto do relator, p. 6.
} 
Corroborando, ainda, tal raciocínio, trago à colação o esclarecimento, colhido do sítio eletrônico da Grande Loja Maçônica do Estado do Rio Grande do Sul, quanto à natureza das atividades que ela desenvolve:

"A Maçonaria é uma Ordem Iniciática mundial. É apresentada como uma comunidade fraternal hierarquizada, constituída de homens que se consideram e se tratam como irmãos, livremente aceitos pelo voto e unidos em pequenos grupos, denominados Lojas ou Oficinas, para cumprirem missão a serviço de um ideal. Não é religião com teologia, mas adota templos onde desenvolve conjunto variável de cerimônias, que se assemelha a um culto, dando feições a diferentes ritos. Esses visam despertar no Maçom o desejo de penetrar no significado profundo dos símbolos e das alegorias, de modo que os pensamentos velados neles contidos, sejam decifrados e elaborados. Fomenta sentimentos de tolerância, de caridade e de amor fraterno. Como associação privada e discreta ensina a busca da Verdade e da Justiça" (grifos meus).

Verifico, então, que a própria entidade declara enfaticamente não ser uma religião e, por tal razão, parece-me irretocável a decisão a quo, a qual, quanto ao tema consignou:

“A prática Maçom é uma ideologia de vida. Não é uma religião. Não tem dogmas. Não é um credo. É uma grande família apenas. Ajudam-se mutuamente, aceitando e pregando a idéia de que o Homem e a Humanidade são passíveis de melhoria e aperfeiçoamento. Como se vê, uma grande confraria que, antes de mais nada, prega e professa uma filosofia de vida. Apenas isto. De certa forma, paradoxal, pois ao mesmo tempo em que prega esta melhoria e aperfeiçoamento do Homem e da Humanidade, só admite em seu seio homens livres (não mulheres) e que exerçam profissão (afirma que deve ser uma 'profissão honesta') que thes assegure meio de subsistência. Os analfabetos não são admitidos, por não possuírem instrução necessária à compreensão dos fins da Ordem".

Por essas razões, conheço parcialmente do recurso extraordinário e, nessa parte, nego-lhe provimento.

É como voto ${ }^{59}$.

Para argumentar em favor de sua tese (de não aplicação da imunidade tributária às lojas maçônicas), o relator recorreu a um texto colhido no sítio virtual da própria recorrente, procurando, assim, conferir e intensificar a legitimidade do que ali estaria escrito, uma vez que, segundo sua compreensão, seria desfavorável à pretensão discutida. Retoricamente, o relator se vale do discurso relatado quase como uma confissão ou admissão do recorrente em seu desfavor. Parece-nos interessante, pois, analisar (no sentido técnico) o texto utilizado pelo relator como argumento contrário à pretensão para, ao mesmo tempo, examinar a correção da compreensão e do julgamento que sobre ele fez para atingir seu objetivo de argumentação.

Procederemos a essa análise, examinando o texto em cinco fragmentos:

59 Voto do relator, p. 6-7. 
a) “A Maçonaria é uma Ordem Iniciática mundial. É apresentada como uma comunidade fraternal hierarquizada, constituída de homens que se consideram e se tratam como irmãos, livremente aceitos pelo voto e unidos em pequenos grupos, denominados Lojas ou Oficinas, para cumprirem missão a serviço de um ideal”.

O relator não se ateve a essa parte do texto. Não enfrentou aspectos, por exemplo, como a predisposição dos integrantes da maçonaria em se considerarem "irmãos", integrantes de uma "fraternidade", nem a ideia de "missão" a que essa conexão poderia conduzi-los. A verdade é que esses elementos estão presentes em religiões mundiais, a começar pelo Cristianismo, a mais professada no Brasil, que considera a todos como filhos de um mesmo “Deus-Pai” e, portanto, “irmãos”. Não foram, contudo, explorados em um esforço de definição ${ }^{60}$.

b) "Não é religião com teologia, mas adota templos onde desenvolve conjunto variável de cerimônias, que se assemelha a um culto, dando feições a diferentes ritos”.

Com base no quanto registrado no sítio virtual da recorrente, o relator afirma que "a própria entidade declara enfaticamente não ser uma religião", o que não condiz estritamente com o texto a que se refere. 0 que consta realmente no texto transcrito é uma declaração de não ser a maçonaria uma religião "com teologia”, com sentido bem diverso da simples negação em ser religião. No entanto, de acordo com autores como Jostein Gaarder, Victor Hellern e Henry Notaker, a crença, a devoção e mesmo o culto a deuses não seria um requisito essencial à ideia de religião, alinhando-se à existência histórica de grandes religiões mundiais sem teologia, a exemplo do budismo clássico ${ }^{61}$ e do confucionismo ${ }^{62}$.

\footnotetext{
${ }^{60}$ De acordo com Luiz Alberto Warat (Introdução geral ao direito I: Interpretação da lei: temas para uma reformulação. Porto Alegre: Sergio Antonio Fabris Editor, 1994. p. 32), todos os objetos apresentam características ora comuns, ora evidentemente diferentes. Com base nisso, afirma que definir seria um processo de classificação a partir da seleção de um critério para atribuir-se um rótulo a determinada classe de objetos. A categorização de dois ou mais objetos na mesma classe pressuporia a decisão de conferir maior peso às características que os objetos têm em comum, afastando aquelas que os distinguiria entre si. Em arremate, afirma o autor que classificar "é efetuar um processo teórico visando estruturar coisas, fatos, objetos ou dados, levando em consideração certas propriedades comuns", formando, assim, classes e subclasses.

61 "Em tempos antigos o culto religioso consistia inteiramente em venerar as relíquias do Buda ou de outros homens santos. Originalmente as relíquias eram guardadas em pequenos montes de terra (stupas). Aos poucos estas se transformaram naquelas construções características, em forma de sino ou de domo, que hoje chamamos de pagodes" (GAARDER, Jostein; HELLERN, Victor; NOTAKER, Henry. 0 livro das religiões. Tradução Isa Mara Lando. São Paulo: Companhia das Letras, 1989 [copyright]. E-book. Locais do Kindle 1118-1121). Cf. ainda, já citado: LAMBERT, Yves. 0 nascimento das religiões: da pré-história às religiões universalistas. São Paulo: Edições Loyola, 2011.

62 "Sua ideologia era o confucionismo, um conjunto de pensamentos, regras e rituais sociais desenvolvidos pelo filósofo K'ung-Fu-Tzu (ou, na forma latina, Confucius) cujas doutrinas prevaleceram na China até a queda do imperador" (GAARDER, Jostein; HELLERN, Victor; NOTAKER, Henry. O livro das religiões.
} 
Fiando-se completamente na primeira parte, o relator passa em branco sobre a parte final desse trecho, segundo a qual a recorrente admitiria (agora sim) a prática de cerimônias semelhantes a cultos, com diferentes ritos. A natureza instrumental das cerimônias e dos ritos fica nítida na passagem seguinte, a partir de que o tribunal teria condições de uma análise mais precisa sobre a existência ou não de algum significado religioso.

c) "Esses visam despertar no Maçom o desejo de penetrar no significado profundo dos símbolos e das alegorias, de modo que os pensamentos velados neles contidos, sejam decifrados e elaborados".

Essa passagem é igualmente ignorada na decisão, o que ajudaria a explicar parte da proposta das reuniões na maçonaria, suas cerimônias (assemelhadas a cultos) e seus ritos diferenciados. A ideia que parece subjazer aqui é a de inspiração pela busca do conhecimento, aspecto apontado em doutrina como essencial a algumas religiões mundiais ${ }^{63}$.

d) "Fomenta sentimentos de tolerância, de caridade e de amor fraterno".

Passagem igualmente negligenciada no voto do relator e na decisão recorrida. De acordo com esse texto, a maçonaria teria como objetivo fomentar valores e práticas como tolerância, caridade e amor fraterno, todos associados em doutrina a grandes religiões mundiais, inclusive as grandes correntes religiosas professadas no Brasil.

e) "Como associação privada e discreta ensina a busca da Verdade e da Justiça”.

Também essa última passagem foi negligenciada na decisão, embora a expressão "associação privada" tenha sido grifada, aparentemente como sutil recurso de distanciamento em relação ao conceito de "entidade religiosa". [TRECHO SUPRIMIDO]

Em seguida, após enfatizar que o recorrente teria negado ser entidade religiosa, o relator recupera trecho da decisão recorrida, incorporando as ideias ali contidas, na forma de discurso relatado, como parte de sua fundamentação. 0 tom é de nítida conformidade, quase como se a argumentação que acabara de empreender desembocasse logicamente no conteúdo da decisão cujo trecho transcreve na sequência. Vamos, assim, analisar a referida passagem para examinar se ela realmente corresponde à fundamentação do relator.

a) "A prática Maçom é uma ideologia de vida".

Tradução Isa Mara Lando. São Paulo: Companhia das Letras, 1989 [copyright]. E-book. Locais do Kindle 1330-1332).

63 "Segundo uma ideia central dos Upanishads, é a ignorância do homem que o amarra ao ciclo da reencarnação. Compreender a verdadeira natureza da existência - o oposto da ignorância - será, portanto, um caminho para a salvação. É apenas quando o homem adquire o reto conhecimento que ele é redimido da implacável roda da transmigração" (GAARDER, Jostein; HELLERN, Victor; NOTAKER, Henry. 0 livro das religiões. Tradução Isa Mara Lando. São Paulo: Companhia das Letras, 1989 [copyright]. E-book. Locais do Kindle 749-751). 
O texto afirma que a maçonaria e as práticas maçons são uma “ideologia de vida" como estratégia de argumentação, visando afastar-lhe o conceito de religião e práticas religiosas através da criação de uma imagem de diversidade, antagonismo, oposição, recurso ideológico a que John B. Thompson se referiria pelo nome de "fragmentação por diferenciação"64. Até mesmo a utilização da palavra "ideologia” como núcleo da pretensa definição seria, no mínimo, questionável, pelo menos do ponto de vista dos conceitos praticados nas ciências humanas ${ }^{65}$.

O relator parece sugerir que a ideia de "filosofia de vida" traduza a adesão a valores elevados e transcendentais, sem conteúdo necessariamente religioso. Ainda assim, o autor do texto se veria em dificuldades para afastar a significação (reconhecida doutrinariamente como) religiosa, por exemplo, do budismo, do confucionismo e do hinduísmo ${ }^{66}$, fortemente associados à ideia de filosofia ou modo de vida.

b) “Não é uma religião. Não tem dogmas. Não é um credo. É uma grande família apenas".

A negação da natureza religiosa da maçonaria aparece finalmente de forma direta e explícita. Em seguida, a construção textual utilizada parece enunciar razões para a proposição inicial, segundo a qual a maçonaria "não é uma religião". Para isso, o texto afirma que ela (a maçonaria) "não tem dogmas", “não é um credo", traduzindo apenas uma "grande família”.

De acordo com o texto, para ser religião, a maçonaria teria que ter dogmas e credos, de forma que, não os tendo, não poderia ser religião. No conteúdo da decisão, tais afirmações não são minimamente fundamentadas, ou seja, não há qualquer esforço em convencer o leitor de que realmente não haja dogmas ou credos, expressões que, inclusive, teriam que ser definidas no trabalho de persuasão. Em suma, a afirmação de que a maçonaria não possui ou professa dogmas nem credos e de que tais elementos sejam essenciais às religiões mundiais ${ }^{67}$, servindo como fundamento à decisão, carece, ela mesma, de maior (trabalho de) fundamentação.

\footnotetext{
64 THOMPSON, John B. Ideologia de cultura moderna: teoria social crítica na era dos meios de comunicação de massa. 9. ed. Petrópolis, RJ: Vozes, 2011. p. 87.

65 THOMPSON, John B. Ideologia de cultura moderna: teoria social crítica na era dos meios de comunicação de massa. 9. ed. Petrópolis, RJ: Vozes, 2011. p. 44 ss. Conferir ainda ZIZEK, Slavoj (org.). Um mapa da ideologia. Rio de Janeiro: Contraponto, 1996, especialmente a introdução do organizador (p. 7 ss.).

66 "De resto, geralmente ele [o hinduísmo] é concebido pelos especialistas e pelos próprios hindus como um modo de vida, uma civilização, e não uma religião no sentido ocidental do termo" (LAMBERT, Yves. 0 nascimento das religiões: da pré-história às religiões universalistas. São Paulo: Edições Loyola, 2011. p. 438).

67 "Diferentemente das outras religiões mundiais (budismo, cristianismo e islã), o hinduísmo não tem fundador, nem credo fixo nem organização de espécie alguma." (GAARDER, Jostein; HELLERN, Victor; NOTAKER, Henry. 0 livro das religiões. Tradução Isa Mara Lando. São Paulo: Companhia das Letras, 1989 [copyright]. E-book. Locais do Kindle 643-644).
} 
c) "Ajudam-se mutuamente, aceitando e pregando a ideia de que o Homem e a Humanidade são passíveis de melhoria e aperfeiçoamento".

Novamente as ideias de "fraternidade" (ajuda mútua) e "busca pelo conhecimento" (melhoria e aperfeiçoamento) são destacadas como inerentes à maçonaria. No texto, são apresentadas como argumentos para distinguir-se a maçonaria de quaisquer religiões, sem fundamentação da premissa de que serem tais qualificativos conflitantes com a pretensão de enquadramento como entidade religiosa.

d) "Como se vê, uma grande confraria que, antes de mais nada, prega e professa uma filosofia de vida. Apenas isto".

A passagem acima se utiliza de um operador argumentativo $0^{68}$ para sinalizar a evidência e indiscutibilidade da visão que propõe na sequência. No corpo, eis que surge a ideia de "filosofia de vida" seguida e professada por uma comunidade de pessoas que se consideram irmãos. Uma confraria. A utilização do operador argumentativo "apenas isto" ao final tem a intenção retórica de expurgar quaisquer outras características que pudessem implicar o reconhecimento de religiosidade à maçonaria, colocando um fim à discussão.

e) "De certa forma, paradoxal, pois ao mesmo tempo em que prega esta melhoria e aperfeiçoamento do Homem e da Humanidade, só admite em seu seio homens livres (não mulheres) e que exerçam profissão (afirma que deve ser uma 'profissão honesta') que lhes assegure meio de subsistência. Os analfabetos não são admitidos, por não possuírem instrução necessária à compreensão dos fins da Ordem".

Nesse trecho em particular, dotado de fina ironia, o texto parece contestar a nobreza dos objetivos declarados (melhoria e aperfeiçoamento do Homem e da Humanidade) a partir de sua oposição à natureza restritiva dos requisitos de admissibilidade à condição de maçom. Considerando que o emprego dessa passagem também é feito como argumento contrário à posição de que a maçonaria seria uma religião, a estratégia argumentativa do texto está em sugerir, implicitamente, a ampla acessibilidade como essencial ao conceito de religião. 0 argumento, assim utilizado, desconsidera a existência de religiões (amplamente aceitas como tal) de acessibilidade fortemente restrita ${ }^{69}$.

\footnotetext{
${ }^{68}$ Sobre operadores argumentativos, cf. COLARES, Virgínia. Análise Crítica do Discurso Jurídico (ACDJ): o caso Genelva e a (im)procedência da mudança de nome. ReVEL, vol. 12, n. 23, 2014.

${ }^{69} \mathrm{Em}$ sua forma ortodoxa, o judaísmo, por exemplo, seria acessível apenas a quem tivesse mãe judia e não professasse qualquer outra religião, o que não deixa de ser uma forma de restrição. Nesse sentido: "0 Estado de Israel define o judeu como 'alguém cuja mãe é judia e que não pratica nenhuma outra fé'. Aos poucos essa definição foi ampliada para incluir o cônjuge". (GAARDER, Jostein; HELLERN, Victor; NOTAKER, Henry. $O$ livro das religiões. Tradução Isa Mara Lando. São Paulo: Companhia das Letras, 1989
} 
Com base nesses fundamentos, o relator, tendo conhecido o recurso no que dizia respeito à imunidade da CF, art. 150, VI, 'b', negou-lhe provimento, recusando a imunidade à loja maçônica demandante. Decidiu, portanto, que a maçonaria não é religião, que seus cultos não são religiosos e que, finalmente, suas lojas ou oficinas não são templos para os fins da imunidade tributária pretendida.

\subsection{0 debate entre os ministros}

O debate que tomou lugar após o voto do relator nos trouxe pinceladas muito vivas em busca de uma ideia de religião "coletivamente" ou "colegiadamente" formada. Como se pode observar a partir das transcrições, em momento algum qualquer dos ministros procurou conceituar "religião", mas a maioria deles revelou traços do que acreditam ser os elementos ou requisitos do conceito de religião.

Superada a questão da possibilidade de conhecer o recurso extraordinário com base na pretensão fundada no art. 150 , VI, ' $C$ ', da CF/88, os ministros passaram a discutir a questão da extensão à maçonaria da imunidade prevista no art. 150, VI, 'b', da CF/88, tendo sido, logo no início, enfatizada pelo ministro Ayres Britto a expressão “templos de qualquer culto", contida no texto constitucional. O min. Marco Aurélio recorreu ao dicionário para registrar significados de "culto", apresentando como tal a "adoração ou homenagem à divindade [que identifica, imediatamente, com o "Arquiteto Maior do Universo, Deus"] em qualquer de suas formas e em qualquer religião". Logo em seguida, o min. Marco Aurélio utiliza a seguinte frase para falar sobre os objetivos da maçonaria:

Agora, se percebermos os objetivos, é tida como uma 'associação de caráter universal, cujos membros cultivam a filantropia, justiça social, classismo, humanidade, princípios da liberdade, democracia, igualdade, aperfeiçoamento intelectual e fraternidade. É uma associação iniciática, filosófica, filantrópica e educativa'70.

Uma leitura literal do argumento do min. Marco Aurélio não diria que ele teria afirmado a natureza religiosa da maçonaria a partir dos objetivos ali enumerados. No entanto, não foi exatamente assim que os ministros receberam a mensagem. A transcrição sugere que, fazendo a

[copyright]. E-book. Locais do Kindle 1691-1693). Cf. ainda CRAWFORD, Roberto. O que é religião? Petrópolis: Vozes, 2005. p. 81.

${ }^{70}$ Debates, p. 6. 
ISSN 1981-3694

(DOI): $10.5902 / 1981369435079$

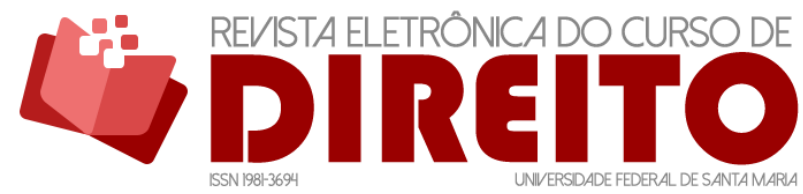

A IMUNIDADE TRIBUTÁRIA DOS TEMPLOS E O CONCEITO DE RELIGIÃO NO SUPREMO TRIBUNAL FEDERAL

ROGÉRIO ROBERTO GONÇALVES DE ABREU HÉLIO SILVIO OURÉM CAMPOS VIRGÍNIA COLARES

leitura correta, entenderam os ministros que o min. Marco Aurélio identificava tais objetivos como afetos a instituições de natureza religiosa. Tanto assim que a reação do colegiado foi de franca oposição. De fato, o min. Lewandowski salientou a ausência de universalidade da maçonaria ("Mas que exclui mulheres e analfabetos"), seguido do min. Ayres Britto, que lhe afastou terminantemente a natureza religiosa ("Mas não religiosa”).

Nesse ponto, o min. Marco Aurélio foi enfático em afirmar que não veria, "na referência a templo, necessariamente uma religião". Seu argumento, portanto, não seria no sentido de que a maçonaria seria titular da imunidade por ser religião e desenvolver cultos religiosos, mas, antes, porque os cultos referidos na CF não seriam necessariamente religiosos. Em um e em outro caso - ou seja, tanto para reconhecer a natureza religiosa da maçonaria quanto para afastar a religiosidade de seus cultos - definir o que seria “religião" seria, naquele contexto, um estágio necessário ao processo de tomada de decisão em desenvolvimento.

Retrucando, o min. Ayres Britto afirmou que via, sim, a exigibilidade da natureza religiosa do culto referido pela Constituição. Citou o texto constitucional para dizer que, nos três momentos em que mencionava "culto", em dois a expressão utilizada era "cultos religiosos". Pouco depois, ele retoma a CF e, referindo-se à expressão "cultos e suas liturgias", identifica-as à "liturgia religiosa", concluindo que "a referência à religiosidade me parece sair diretamente da Constituição".

Aproveitando a oportunidade, os min. Lewandowski e Carmem Lúcia afirmaram que a maçonaria se identificaria mais propriamente com uma "cientologia" ou uma "filosofia de vida". 0 argumento, nesse caso, estava em traçar uma fronteira distintiva entre cientologia e filosofia de vida, de um lado, e religião, de outro, com o objetivo de apresentar o resultado retórico de distanciar as duas categorias de realidades (fragmentação ideológica). Apesar de "elogiável”, diz o min. Ayres Britto que não se confundiria com religião. O min. Lewandowski menciona que a maçonaria deveria realizar "algumas reuniões que se assemelham a cultos, rituais", mas, ainda assim, afastando, no contexto de sua fala, qualquer identificação com caracteres religiosos.

Após uma passagem em que o min. Marco Aurélio, referindo-se a outras entidades que foram cogitadas a receber a imunidade tributária, começava a construir um argumento fundado na necessidade de interpretação ampla (o que vem a fazer em seu voto-vista), o min. Ayres Britto cita o art. 19, I, da CF/88, para destacar a expressão "cultos religiosos ou igrejas". Uma interessante sequência tem lugar nesse momento. Ao afirmar ser "[e]vidente que maçonaria não é uma Igreja, não é um templo nesse sentido constitucional, de culto à divindade, a postular uma transcendência espiritual”, o min. Ayres Britto parece tecer o esboço de um conceito de 
ISSN 1981-3694

(DOI): $10.5902 / 1981369435079$

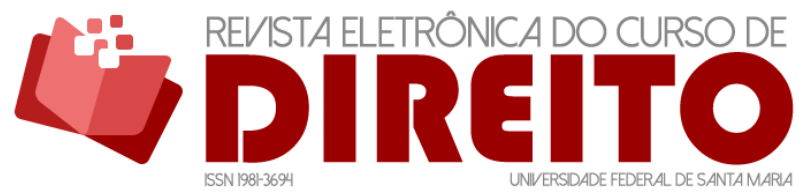

A IMUNIDADE TRIBUTÁRIA DOS TEMPLOS E O CONCEITO DE RELIGIÃO NO SUPREMO TRIBUNAL FEDERAL

ROGÉRIO ROBERTO GONÇALVES DE ABREU HÉLIO SILVIO OURÉM CAMPOS VIRGÍNIA COLARES

religião, no que é seguido e acrescido pela min. Carmem Lúcia, destacando que o “Presidente chegou a falar que não há dogmas, não há exatamente o que seria a centralidade do conceito de religião", sendo reverberada pelo min. Ayres Britto que afirmou, quase como um pensamento alto: "A centralidade do conceito de religião".

0 texto nos mostra uma atividade pendular nos fundamentos orais dos ministros, ora referindo-se à maçonaria (procurando afastá-la do conceito de religião), ora voltando os olhos à ideia de religião (distanciando-lhe as características identificáveis das que possuiria a maçonaria). Assim é que, em seguida ao que sucedeu no parágrafo anterior, a maçonaria é descrita como "[u]ma entidade de ajuda mútua de seus integrantes” (min. Lewandowski), “[e]m fins eminentes, sem nenhuma dúvida”, compreendendo "o aperfeiçoamento da humanidade" (min. Ayres Britto), cujos membros "fazem filantropia” (min. Lewandowski).

O julgamento não prosseguiu naquele dia, dado o pedido de vista do min. Marco Aurélio, que afirmou não se convencer da ausência de imunidade tributária, pedindo a chance de apresentar seu voto após dotar-se de maior conhecimento da matéria. Até aquele momento, como descrito na ata de julgamento do dia 13 de abril de 2010, os ministros Ricardo Lewandowski (relator e presidente), Ayres Britto, Dias Toffoli e Carmen Lúcia já haviam votado pelo conhecimento parcial do recurso e, nessa parte, por seu não provimento.

\subsection{0 voto-vista}

A continuação do julgamento do RE $562.351 /$ RS somente ocorreria em 04 de setembro de 2012, quase dois anos e meio após a formação da maioria que admitiu parcialmente o recurso, negando-lhe provimento nessa parte, recusando à maçonaria o reconhecimento da imunidade tributária concedida pela Constituição aos "templos de qualquer culto" (art. 150, VI, 'b', CF/88). O voto-vista apresentado pelo min. Marco Aurélio divergiu dos demais para reconhecer a imunidade tributária em questão. Seus fundamentos são particularmente interessantes e revelam aquele que talvez seja o mais sincero esforço em densificar, para os fins da imunidade tributária dos templos de qualquer culto, o conceito de religião no STF.

Situando o confronto de teses no julgamento, o min. Marco Aurélio afirmou que, “[s]egundo o entendimento revelado no acórdão recorrido, maçonaria não é religião, mas uma confraria que professa certa filosofia de vida, e não tem a natureza de entidade assistencial". Referindo-se ao voto do relator no julgamento do recurso e acrescentando que fora seguido pelos demais membros da corte na sessão originária, escreveu: 
Quanto à incidência da imunidade reconhecida aos templos, afastou-a por não considerar a maçonaria uma religião. Recorreu à doutrina para afirmar que tal hipótese de imunidade está vinculada à liberdade religiosa. Em outras palavras, a imunidade consubstanciaria um meio de que o Estado se vale para evitar embaraços à livre manifestação da religiosidade. Logo, a maçonaria estaria fora da teleologia da norma constitucional, circunscrita à proteção dos 'cultos religiosos'. Asseverou, alfim, que as imunidades, ao contrário das liberdades, devem ser interpretadas restritivamente ${ }^{71}$.

A descrição que empreendeu o min. Marco Aurélio nos parece exata: a imunidade tributária em questão estava sendo negada à loja maçônica por entender o tribunal que o favor constitucional seria restrito aos templos em que se realizassem cultos religiosos, de forma que, não sendo a maçonaria uma religião e não realizando cultos religiosos, suas edificações não poderiam ser consideradas "templos de qualquer culto", como previsto pela Constituição Federal. Em síntese e no que interessa, o STF negava, até aquele momento, que a maçonaria com todas as suas características, seus objetivos, seus rituais etc. - se enquadrasse no conceito de organização ou entidade religiosa.

O min. Marco Aurélio discorreu longamente, no princípio, para atacar a última afirmação contida na descrição acima transcrita: a interpretação restritiva das imunidades. 0 desfecho dessa parte do voto-vista ataca a conclusão do voto do relator, acusando-a de ser mais restritiva que a interpretação literal do art. 150, VI, 'b', da CF. Ele marca a transição com o seguinte parágrafo:

A Constituição não restringiu a imunidade à prática de uma religião enquanto tal, mas apenas ao que for reconhecido como templo de qualquer culto. Com essa premissa maior, passo ao exame da menor, que consiste em qualificar a maçonaria como religião - ou, ao menos, como prática que expressa religiosidade, podendo ser designada como culto ${ }^{72}$.

De acordo com o primeiro período, parecia até que o min. Marco Aurélio atacaria o voto do relator, negando a necessidade do aspecto religioso para o enquadramento do culto e do templo na moldura da imunidade. Em vez disso, podemos observar, pelo restante da frase, que optou por discutir o conceito de religiosidade, propondo uma abertura em relação à compreensão já manifestada pelos demais ministros da Primeira Turma do STF.

\footnotetext{
71 Voto-vista, p. 1

72 Voto-vista, p. 4.
} 
Começou afirmando estarem em jogo três conceitos: "religião", "culto" e "templo". Quanto ao primeiro, destacou ser objeto de disputa em áreas diversas do conhecimento (sociologia, antropologia, teologia) e, recorrendo ao Dicionário Aurélio Eletrônico, ofereceu as três seguintes definições:

1. Crença na existência de uma força ou forças sobrenaturais, considerada(s) como criadora(s) do Universo, e que como tal deve(m) ser adorada(s) e obedecida(s);

2. A manifestação de tal crença por meio de doutrina e ritual próprios, que envolvem, em geral, preceitos éticos;

(...)

8. Qualquer filiação a um sistema específico de pensamento ou crença que envolve uma posição filosófica, ética, metafísica, etc. ${ }^{73}$.

No parágrafo seguinte, o min Marco Aurélio empreende aquele que, em nosso sentir, pode ser considerado o mais sério esforço em busca da construção de um conceito operacional de religião, ainda que, num primeiro momento, de utilidade restrita à resolução da controvérsia jurídico-constitucional submetida ao julgamento do STF. Dividimos o parágrafo em duas partes para trazer, inicialmente, a proposição segundo a qual a maçonaria seria uma forma de religião em sentido amplo e, em seguida (grifado), a figuração dos traços que a identificariam como entidade religiosa, equivalendo à descrição dos requisitos do conceito lato sensu de religião.

Numa perspectiva menos rígida do conceito de religião, certamente se consegue classificar a maçonaria como uma corrente religiosa, que contempla física e metafísica. São práticas ritualísticas que somente podem ser adequadamente compreendidas no interior de um conceito mais abrangente de religiosidade. Há uma profissão de fé em valores e princípios comuns, inclusive em uma entidade de caráter sobrenatural capaz de explicar fenômenos naturais - basta ter em conta a constante referência ao "Grande arquiteto do Universo", que se aproxima da figura de um deus. Está presente, portanto, a tríplice marca da religião: elevação espiritual, profissão de fé e prática de virtudes ${ }^{74}$ (grifos nossos).

Podemos facilmente identificar no texto os seguintes traços apontados pelo min. Marco Aurélio como inerentes à essência do conceito amplo de religião que propõe $\mathrm{e}^{75}$ :

\footnotetext{
${ }^{73}$ Voto-vista, p. 4-5.

74 Voto-vista, p. 5.

75 Parece-nos conveniente registrar, no ponto, que não manifestamos, implícita ou explicitamente, qualquer aderência ao mérito do esboço conceitual de religião que o min. Marco Aurélio se empenha em construir no texto de seu voto-vista. Nosso objetivo, no presente trabalho, é destacar que seu esforço
} 
a) profissão de fé em valores e princípios comuns;

b) notadamente, em uma entidade de caráter sobrenatural capaz de explicar fenômenos naturais (com referência ao Grande Arquiteto do Universo, figura próxima a um deus);

c) a presença da tríplice marca da religião, ou seja, elevação espiritual, profissão de fé e prática de virtudes.

Após nova digressão sobre a necessidade de se considerar a religião sob um ponto de vista amplo em atenção ao pluralismo como valor acolhido pela Constituição Federal, o min. Marco Aurélio volta os olhos à maçonaria em sua individualidade e, utilizando o Dicionário Enciclopédico da Maçonaria, transcreve a seguinte passagem:

(...) a Sociedade dos Franco-Maçons converteu-se numa instituição essencialmente distinta da dos operários construtores, dedicada à realização de um objetivo mais elevado, mais moral e, por isso mesmo, susceptível de difundirse pelo mundo inteiro, ao ponto de chegar a ser uma profissão de fé comum a todo o gênero humano. 0 edifício moral, em cuja construção se devia doravante trabalhar, teria de servir, como o trabalho material dos Maçons, para estabelecer o bem-estar geral na sociedade humana.

0 aperfeiçoamento dos membros da sociedade devia manifestar-se por um conhecimento mais completo do seu ser, por uma maior espontaneidade, por um maior autodomínio e, de uma maneira geral, pela prática de todas as virtudes. Segundo a intenção dos seus reorganizadores, a Franco-Maçonaria estava destinada a fazer dos indivíduos de todas as classes sociais melhores cidadãos, administradores mais escrupulosos do bem-estar geral, pais de família, esposos e amigos perfeitos (citado por Marcelo Linhares, História da Maçonaria, 1992, p. $102)^{76}$.

Com base nesses fundamentos, o min. Marco Aurélio reconheceu haver "inequívocos elementos de religiosidade na prática maçônica". Ponderou ainda que a Constituição Federal protegeria o culto, que consistiria em "rituais de elevação espiritual”, propósito inerente às práticas maçons. Como arremate, o ministro argumentou que as restrições à acessibilidade às lojas maçônicas, apesar de anacrônicas, não seriam aspecto impeditivo à configuração da entidade como religiosa. Salientou, nesse ponto, que "ancestralidade das religiões traz consigo os preconceitos do passado, os quais não impedem o reconhecimento público de seus valores". Ao fim e ao cabo, fixando definitivamente a divergência, o ministro Marco Aurélio, conhecendo parcialmente do recurso extraordinário, deu-lhe provimento nessa parte.

conceitual se apresentou, no caso concreto, como uma empreitada isolada em busca de um objetivo que entendemos como indispensável ao conjunto da decisão que, afinal, foi tomada pela corte.

76 Voto-vista, p. 6. 


\section{CONCLUSÃO}

O modelo de julgamento colegiado adotado nos tribunais brasileiros, em termos simples, segue a técnica da contagem dos votos a partir de suas conclusões, ou seja, do resultado dispositivo da respectiva fundamentação. A decisão da corte se configura pela maioria dos resultados em determinado sentido, não importando se os fundamentos dos votos individuais dos magistrados forem divergentes entre $\mathrm{si}^{77}$. Essa técnica de julgamento termina por ocultar simbolicamente os conflitos internos, fornecendo ao público consumidor da prestação jurisdicional (e do texto, no campo da linguagem) a imagem de consenso, inclusive sobre os fundamentos da decisão.

Por conta desse ocultamento simbólico da divergência, nem sempre é fácil ao jurisdicionado identificar, nas decisões do STF (como de quaisquer tribunais brasileiros), as lacunas e falhas de fundamentação que, a rigor, implicariam a nulidade do ato jurisdicional. A importância dessa questão foi um dos fatores que nos motivou a empreender a pesquisa qualitativa ora desenvolvida, com especial atenção a dois campos que reputamos particularmente delicados: o campo tributário, nos aspectos jurídico e econômico; o campo religioso, nos aspectos social e cultural.

As conclusões que extraímos da pesquisa podem ser dessa maneira sintetizadas:

A) O Supremo Tribunal Federal, cúpula do poder judiciário nacional, como órgão colegiado de julgamento, tem decidido amiúde sobre direitos, deveres e o obrigações tributários relacionados à ideia de religião sem que, em momento algum, haja fixado coletivamente o conceito de religião, seja pela formulação de um conceito operacional próprio, seja pela apropriação de conceito já formulado em outra fonte;

B) A única vez em que o STF discutiu o conceito de religião e, mais particularmente, a ideia sobre o que poderia ou não ser considerado religioso(a) para fins de imunidade tributária dos templos de qualquer culto foi ao ensejo do julgamento do Recurso Extraordinário n. 562.351/RS, iniciado em 2010 e finalizado em 2012, negando-se à maçonaria o reconhecimento da condição de entidade religiosa, como também do caráter religioso de seus cultos;

C) Nesse julgamento, o voto do relator, min. Ricardo Lewandowski, não resolve o problema do que possa ser, afinal, considerado religião ou religioso, preferindo apoiar-se em

77 Para uma análise comparativa entre as técnicas adotadas no Brasil e nos EUA, cf. RODRIGUEZ, José Rodrigo. Como decidem as cortes? Rio de Janeiro: FGV, 2013. E-book. 
ISSN 1981-3694

(DOI): $10.5902 / 1981369435079$

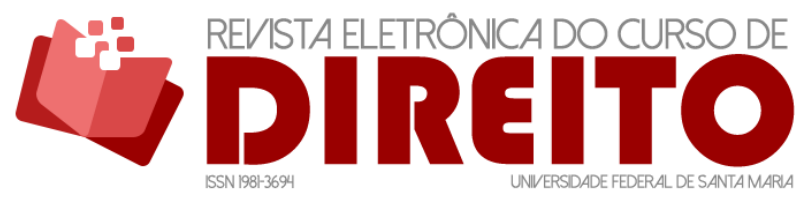

A IMUNIDADE TRIBUTÁRIA DOS TEMPLOS E O CONCEITO DE RELIGIÃO NO SUPREMO TRIBUNAL FEDERAL

ROGÉRIO ROBERTO GONÇALVES DE ABREU HÉLIO SILVIO OURÉM CAMPOS VIRGÍNIA COLARES

interpretação pessoal de texto colhido da página virtual da demandante e em trecho do acórdão recorrido cuja fundamentação também não precisa o que seja religião. Os debates que se seguiram, de maneira pendular, oscilaram entre negar religiosidade à maçonaria e pincelar, de forma solta e esparsa, aspectos que reputavam inerentes à ideia de religião. Em momento algum a corte, por qualquer de seus ministros (exceto o min. Marco Aurélio), procurou organizar esses dados para a formulação de uma imagem suficientemente concreta do que seria "religioso", a fim de que fosse possível - de maneira efetivamente fundamentada - excluir do respectivo âmbito semântico a maçonaria.

D) Apenas o ministro Marco Aurélio, dois anos e meio após o início do julgamento, apresentou, em seu voto-vista, uma tentativa de fixação semântica da ideia de religião. Considerando presentes na prática maçônica "inequívocos elementos de religiosidade”, o ministro destacou os seguintes aspectos como adequados a identificar a presença do caráter religioso: a) profissão de fé em valores e princípios comuns; b) notadamente, em uma entidade de caráter sobrenatural capaz de explicar fenômenos naturais (com referência ao Grande Arquiteto do Universo, figura próxima a um deus); c) a presença da tríplice marca da religião, ou seja, elevação espiritual, profissão de fé e prática de virtudes. Ao final, ficou vencido, votando isoladamente pelo provimento do recurso.

Podemos intuir que a ausência de uma discussão mais apropriada no STF sobre o que se deva entender por religião demonstra o quão arraigada é a noção no íntimo dos julgadores. Esse enraizamento conceitual, por outro lado, advém da consolidação de um mainstream religioso no Brasil que naturaliza a consciência religiosa da maioria do povo brasileiro, ocultando ideologicamente o conflito. Em outras palavras, a noção é tão naturalizada na cultura que se dispensa implicitamente a discussão, quase como se a ideia pertencesse a uma forma de consciência coletiva, um conhecimento comum, evidente, inquestionável. As características "religiosas" destacadas pelos ministros no debate acima examinado - majoritariamente inerentes às religiões dominantes no Brasil - parecem confirmar essa ideia.

\section{REFERÊNCIAS}

ÁVILA, Fabiana. A imunidade tributária dos templos de qualquer culto. Revista da FESDT. Porto Alegre, n. 6, p. 43-63, jul./dez. 2010. 
ISSN 1981-3694

(DOI): 10.5902/1981369435079

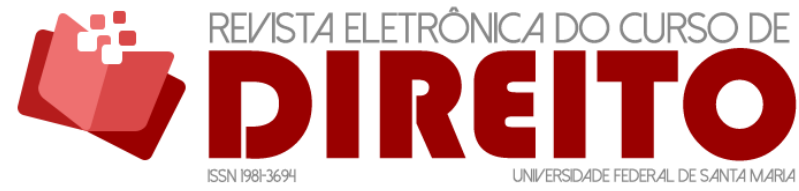

A IMUNIDADE TRIBUTÁRIA DOS TEMPLOS E O CONCEITO DE RELIGIÃO NO SUPREMO TRIBUNAL FEDERAL

ROGÉRIO ROBERTO GONÇALVES DE ABREU HÉLIO SILVIO OURÉM CAMPOS VIRGÍNIA COLARES

BRASIL. Constituição Política do Império do Brasil. Rio de Janeiro: outorgada pelo Imperador D. Pedro I, 1824. Disponível em:

http://www.planalto.gov.br/ccivil_03/Constituicao/Constituicao24.htm. Acesso em: 03 jun. 2020.

BRASIL. Supremo Tribunal Federal (1. Turma). Recurso Extraordinário n. 562.351/RS. Relator: Min. Ricardo Lewandowski, 04 set. 2012, publicado em 14 dez. 2012. Disponível em: http://redir.stf.jus.br/paginadorpub/paginador.jsp?docTP=TP\&docID=3195619. Acesso em: 04 jun. 2020.

CARRAZZA, Roque Antônio. Curso de Direito Constitucional Tributário. 23. ed. São Paulo: Malheiros, 2007.

CARRAZZA, Roque Antônio. Curso de direito constitucional tributário. 29. ed. São Paulo: Malheiros, 2013.

COÊLHO, Sacha Calmon Navarro. Comentários à Constituição de 1988 - Sistema Tributário. 10. ed. Rio de Janeiro: Forense, 2006.

COÊLHO, Sacha Calmon Navarro. Curso de direito tributário. 17. ed. Rio de Janeiro: Forense, 2020. E-book.

COLARES, Virgínia. Análise Crítica do Discurso Jurídico (ACDJ): o caso Genelva e a (im)procedência da mudança de nome. ReVEL, vol. 12, n. 23, 2014.

CRAWFORD, Robert. 0 que é religião? Petrópolis: Vozes, 2005.

FAIRCLOUGH, Norman. Discurso e mudança social. 2. ed. Brasília: Editora Universidade de Brasília, 2016 [1992].

GAARDER, Jostein; HELLERN, Victor; NOTAKER, Henry. O livro das religiões. Tradução Isa Mara Lando. São Paulo: Companhia das Letras, 1989 [copyright]. E-book.

LAMBERT, Yves. 0 nascimento das religiões: da pré-história às religiões universalistas. São Paulo: Edições Loyola, 2011.

MARTON, Ronaldo Lindimar José. A imunidade tributária dos templos de qualquer culto na interpretação da Constituição adotada pelo Supremo Tribunal Federal. Consultoria Legislativa. Brasília, Câmara dos Deputados, fev. 2013. Disponível em: http://www2.camara.leg.br/acamara/documentos-e-pesquisa/estudos-e-notas-tecnicas/areas-daconle/tema20/CP13006_1.pdf. Acesso em: 20 ago. 2018. 
RESENDE, Viviane de Melo; RAMALHO, Viviane. Análise de discurso crítica. 2. ed. São Paulo: Contexto, 2017.

RODRIGUEZ, José Rodrigo. Como decidem as cortes? Rio de Janeiro: FGV, 2013. E-book.

THOMPSON, John B. Ideologia de cultura moderna: teoria social crítica na era dos meios de comunicação de massa. 9. ed. Petrópolis: Vozes, 2011.

TORRES, Ricardo Lobo. Curso de direito financeiros e tributário. 18. ed. Rio de Janeiro: Renovar, 2011.

WARAT, Luiz Alberto. Introdução geral ao direito I: Interpretação da lei: temas para uma reformulação. Porto Alegre: Sergio Antonio Fabris Editor, 1994.

ZIZEK, Slavoj (org.). Um mapa da ideologia. Rio de Janeiro: Contraponto, 1996.

Recebido em: 06.10.2018 / Revisões requeridas em: 04.05.2020 / Aprovado em: 12.06.2020 / Publicado em: 07.07.2020

\section{COMO FAZER REFERÊNCIA AO ARTIGO (ABNT):}

ABREU, Rogério Roberto Gonçalves de; CAMPOS, Hélio Silvio Ourém; COLARES, Virgínia. A imunidade tributária dos templos e o conceito de religião no supremo tribunal federal. Revista Eletrônica do Curso de Direito da UFSM, Santa Maria, RS, v. 15, n. 2, e35079, maio./ago. 2020. ISSN 1981-3694. DOI:

http://dx.doi.org/10.5902/1981369435079. Disponível em:

https://periodicos.ufsm.br/revistadireito/article/view/35079. Acesso em: dia mês. ano.

Direitos autorais 2020 Revista Eletrônica do Curso de Direito da UFSM

Editores responsáveis: Rafael Santos de Oliveira e Angela Araujo da Silveira Espindola

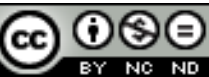

Esta obra está licenciada com uma Licença Creative Commons Atribuição-NãoComercial-SemDerivações 4.0 Internacional.

\section{SOBRE OS AUTORES}

Rogério Roberto GonçALVES de ABREU

Doutorando em Direito, Processo e Cidadania pela Universidade Católica de Pernambuco - UNICAP/PE. Mestre em Direito Econômico pela Universidade Federal da Paraíba - UFPB (2008). Pós-graduado em Direito Fiscal e Tributário pela Universidade Cândido Mendes - UCAM/RJ (2002). Professor dos cursos de graduação e de pós-graduação em Direito do Centro Universitário de João Pessoa (UNIPÊ/PB). Juiz federal.

\section{HÉLIO SILVIO OURÉM CAMPOS}

Possui graduação, em Direito, pela Universidade Federal de Pernambuco (Vestibular Unificado de 1982 - $1^{\circ}$ lugar - 955,70 a 1986, conclusão do Curso -Laureado); Mestrado em Direito Público pela Universidade Clássica de Lisboa - equivalência (junho de 2001); Mestrado em Direito Tributário pela Universidade Federal de Pernambuco (novembro de 1993); Doutorado em Direito pela Universidade Federal de Pernambuco (outubro de 2002) e Doutorado em Direito pela Universidade Clássica de Lisboa (abril de 2002). Pós-Doutorado pela Universidade Clássica de Lisboa (2008-2009)- PHD em Direito Constitucional Tributário. Pós-Doutorado pela Universidade Autónoma de Lisboa (2018-2019) - Economia do bem-estar social. Juiz Federal 
ISSN 1981-3694

(DOI): $10.5902 / 1981369435079$

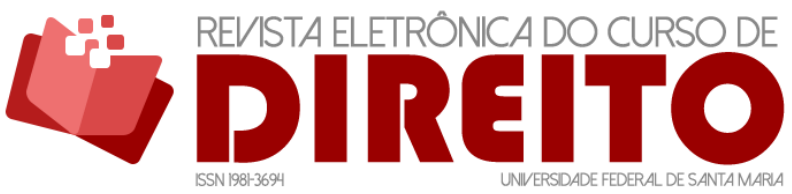

A IMUNIDADE TRIBUTÁRIA DOS TEMPLOS E O CONCEITO DE RELIGIÃO NO SUPREMO TRIBUNAL FEDERAL

ROGÉRIO ROBERTO GONÇALVES DE ABREU HÉLIO SILVIO OURÉM CAMPOS VIRGÍNIA COLARES

Titular da $6^{\mathrm{a}}$ Vara, na Seção Judiciária do Estado de Pernambuco, havendo, desde o ano de 2.000, exercido, por várias oportunidades (26 Convocações), a função de Desembargador Convocado no Egrégio Tribunal Regional Federal da $5^{\mathrm{a}}$ Região. Foi convocado (última convocação), como Desembargador Federal, para compor o Eg. Tribunal Regional Federal da $5^{\mathrm{a}}$ Região, a partir de 09.05.2013 (Ato da Presidência do Eg. TRF5 n. 270/2013, de 09.05.2013). Mais recentemente, também esteve convocado entre os meses de janeiro a março de 2011; março e abril de 2010 e outubro a novembro de 2009. Ex-Membro da Turma Recursal dos Juizados Especiais Federais/PE e Ex-membro da Turma Nacional de Uniformização em Brasília - Distrito Federal (2003-2007). Professor da Escola Superior da Magistratura do Estado de Pernambuco, desde 1989. Professor Titular, desde 01.09.2005, da Graduação, do Mestrado e do Doutorado e Membro do Conselho Superior e do Colegiado do Curso de Direito da Universidade Católica do Estado de Pernambuco. Líder do Grupo de Pesquisa - CNPQ: "Política e Tributação: aspectos materiais e processuais". Ex-Procurador do Município do Recife, Ex-Procurador do Estado de Pernambuco e ExProcurador Federal. Foi Assessor do Relator da Comissão de Sistematização da Assembléia Constituinte do Estado de Pernambuco-1988/1989 e Membro da Comissão de Sistematização Legislativa dela decorrente. Além de várias participações como Palestrante nos Estados brasileiros (Pernambuco, Bahia, Goiás, Sergipe, Piauí, Paraíba, Espírito Santo, Rio de Janeiro, Distrito Federal etc.), também atuou como Expositor na França, na Espanha e em Portugal. Tem livros e vários artigos publicados, no Brasil e na Europa, com ênfase em Direito Tributário, Direito Processual, Direito Constitucional e Direito Previdenciário. (www.ourem.web44.net) Vide E-book (Livro eletrônico): Economia versus Democracia in www.ourem.cjb.net; www.trf5.jus.br/esmafe e http://bdjur/jspui/handle/2011/29753 (SUPERIOR TRIBUNAL DE JUSTIÇA). Lançamento nacional, em 19 de maio de 2010, no Espaco Cultural do SUPERIOR TRIBUNAL DE JUSTICA, em Brasília. Vide Livro: O Poder da lei versus a Lei do poder - a relativização da lei tributária (junho de 2011, em versões impressa e eletrônica), publicado pela Editora do Conselho da Justiça Federal. Lançamento nacional em 30 de junho de 2011, no Espaço Cultural do SUPERIOR TRIBUNAL DE JUSTIÇA, em Brasília. Cursos ENFAM/2010: Curso de Filosofia do Direito (03 e 04.05.2010), apresentando o Título: "Universidade da Califórnia versus Allan Bake - a discriminação reversa e a democracia inclusiva no Brasil"; Curso de Trabalho Escravo - aspectos penal e trabalhista (25 a 27.08.2010). Avaliador 'ad hoc' da Revista do Centro de Estudos Judiciários, Conselho da Justiça Federal, que opera, em meio eletrônico, desde 2008. Vide Facebook: Localizar - Hélio Silvio Ourém Campos, ouremcampos@hotmail.com e ouremcampos@facebook.com

\section{VIRGíNIA COLARES}

Virgínia Colares é mestre (1992) e doutora (1999) em Linguística pela Universidade Federal de Pernambuco (UFPE). Realizou estágio pós-doutoral em Direito, na Universidade de Brasília, em 2011. Desde 1989, é professora da Universidade Católica de Pernambuco (UNICAP), atuando na graduação, mestrado e doutorado em Direito. Tem experiência na área de Linguística Aplicada ao Direito, atua na linha de pesquisa da Análise Crítica do Discurso Jurídico, construída no âmbito do PPGD-UNICAP. Ministra disciplinas relativas à linguagem jurídica em diversas escolas de magistratura no país. Fundadora da Associação de Linguagem e Direito (ALIDI - www.alidi.com.br) criada no âmbito do Grupo de Pesquisa Linguagem e Direito (Plataforma Lattes CNPq), do qual é líder. è sócia fundadora da Associação Latinoamericana de Estudos do Discurso (ALED), desde 1995. Contato pelo e-mail virginia.colares@unicap.br 